\title{
Effects of Exogenous Gibberellic Acid in Huanglongbing-affected Sweet Orange Trees under Florida Conditions - I. Flower Bud Emergence and Flower Formation
}

\author{
Lisa Tang, Garima Singh, Megan Dewdney, and Tripti Vashisth \\ Citrus Research and Education Center, University of Florida/Institute of \\ Food and Agricultural Sciences, 700 Experiment Station Road, Lake \\ Alfred, FL 33850
}

Additional index words. Candidatus Liberibacter asiaticus, Citrus sinensis, Colletotrichum actutatum, postbloom fruit drop (PFD)

\begin{abstract}
Under Florida conditions, sweet orange (Citrus sinensis) affected by Huanglongbing \{HLB [Candidatus Liberibacter asiaticus (CLas)]\} frequently exhibits irregular flowering patterns, including off-season flowering and prolonged bloom period. Such patterns can increase the opportunity for temporal and spatial proliferation of pathogens that infect flower petals, including the fungal causal agent for postbloom fruit drop (PFD) Colletotrichum acutatum J.H. Simmonds. For the development of strategies to manipulate flowering, the effects of floral inhibitor gibberellic acid $\left(\mathbf{G A}_{3}\right)$ sprayed monthly at full- and half-strength rates $\left(49\right.$ and $25 \mathrm{~g} \cdot \mathrm{ha}^{-1}$, or 33 and 17 $\mathbf{m g} \cdot \mathrm{L}^{-1}$, respectively) with different regimens, starting from September and ending in November, December, or January, on the pattern of spring bloom were evaluated in field-grown HLB-affected 'Valencia' sweet orange at two locations in subsequent February through April for two separate years in this study. To further examine whether $\mathbf{G A}_{3}$ effects on flowering patterns vary in different cultivars, early-maturing 'Navel' sweet orange trees receiving no $\mathrm{GA}_{3}$ or full-strength $\mathrm{GA}_{3}$ monthly in September through January were included. Overall, for 'Valencia' sweet orange, monthly applications of $\mathrm{GA}_{3}$ at $49 \mathrm{~g} \cdot \mathrm{ha}^{-1}$ from September to December not only minimized the incidence of scattered emergence of flower buds and open flowers before the major bloom but also shortened the duration of flowering, compared with the untreated control trees. In addition, exogenous $\mathrm{GA}_{3}$ led to decreased leaf flowering locus $t(F T)$ expression starting in December, as well as reduced expression of its downstream flower genes in buds during later months. When applied monthly from September through January at $49 \mathrm{~g} \cdot \mathrm{ha}^{-1}$, similar influences of exogenous $\mathrm{GA}_{3}$ on repressing flower bud formation and compressing bloom period were observed in 'Navel' sweet orange. These results suggest that by effectively manipulating flowering in HLBaffected sweet orange trees under the Florida climate conditions, exogenous $\mathrm{GA}_{3}$ may be used to reduce early sporadic flowering and thereby shorten the window of $\mathrm{C}$. $\mathrm{acu}$ tatum infection that causes loss in fruit production.
\end{abstract}

In citrus (Citrus sp.), the length of bloom period among individual trees in the same block determines the uniformity of maturity of fruit within a grove. In addition, the flowering pattern in citrus trees, including the duration and intensity of seasonal bloom as well as the occurrence of off-season flowering, is closely related to the flower-infecting

Received for publication 23 June 2021. Accepted for publication 15 Sept. 2021.

Published online 19 November 2021

Current affiliation for L.T.: Appalachian Fruit Research Station, Agricultural Research Service, U.S. Department of Agriculture, 2217 Wiltshire Road, Kearneysville, WV 25430

T.V. is the corresponding author. E-mail: tvashisth@ufl.edu.

This is an open access article distributed under the CC BY-NC-ND license (https://creativecommons. org/licenses/by-nc-nd/4.0/). open flowers infected by $C$. acutatum develop necrotic lesions on petals accompanied with abscission of a large number of young fruitlets at the end of bloom, leaving calyxes, commonly referred to as "buttons," on pedicels surviving for the life of the tree branch (Peres et al., 2005; Timmer and Peres, 2015; Timmer et al., 1994). Once the petals are infected with $C$. acutatum, fungicides cannot keep newly set fruitlets from abscising (Dewdney, 2017; Peres et al., 2002, 2005; Perondi et al., 2020). Therefore, knowledge of citrus flowering regulation and approaches to manipulate flowering, including temporal distribution and intensity of bloom, would be key in PFD management.

For HLB-affected citrus trees in Florida, irregular flowering patterns, such as off-season bloom and prolonged flowering in spring, have been frequently observed (Dewdney, 2017; Peres and Dewdney, 2019; Stover et al., 2016). In Florida, intermittent periods of warm temperatures following winter low temperatures that are sufficient for floral induction $\left(20^{\circ} \mathrm{C}\right.$ day and $15^{\circ} \mathrm{C}$ night temperatures) initiate bud differentiation and thereby lead to multiple waves of bloom, contributing to an extended duration of subsequent flowering (Albrigo, 2004; Valiente and Albrigo, 2002). Furthermore, HLB likely introduces variability in the behavior of flowering by imposing persistent stresses on affected trees. On infection with $C$ Las, the bacterial agent associated with HLB, trees undergo tremendous dieback of feeder roots (Graham et al., 2013; Johnson et al., 2014), which possibly restricts water uptake from the growing substrate (Hamido et al., 2017). Consistently, Tang et al. (2020) documented lower water potential in 'Valencia' sweet orange trees exhibiting severe HLB symptoms compared with mildly symptomatic trees under field conditions, suggesting HLB-affected trees are prone to water-deficit stress in a manner dependent on disease severity. Relevantly, flowering in citrus can be induced by external stimuli, including water-deficit stress (Chica and Albrigo, 2013; Lovatt et al., 1988; Southwick and Davenport, 1986). Limited rainfall during the Florida dry season (from October through May) may further increase the incidence of off-season flowering in HLBaffected trees with a compromised root system (Johnson et al., 2014) in fall and early winter.

To prevent inoculum amplification of pathogens that infect petals of early bloom, including $C$. acutatum, and thereby reduce pesticide usage, strategies to compress and synchronize spring bloom and to eliminate sporadic flowering before the major bloom awaits development. Owing to its inhibitory effect on flowering in citrus (Goldberg-Moeller et al., 2013; Lord and Eckard, 1987; Muñoz-Fambuena et al., 2012), the plant growth regulator $\mathrm{GA}_{3}$ serves as a good candidate to be used for bloom manipulation. Nevertheless, the current knowledge of $\mathrm{GA}_{3}$ with respect to citrus flowering has been limited to healthy trees in groves or greenhouses with no presence of HLB reported. The goal of 
Table 1. Application rates (25 and $49 \mathrm{~g} \cdot \mathrm{ha}^{-1}$ ) and regimens (three, four, and five monthly applications) of gibberellic acid ( $\left.\mathrm{GA}_{3}\right)$ treatments to Huanglongbing-affected 'Valencia' and 'Navel' sweet orange for 3 consecutive years in 2016-17, 2017-18, and 2018-19.

\begin{tabular}{lcll}
\hline Treatment name & $\mathrm{GA}_{3}$ application rate $\left(\mathrm{g} \cdot \mathrm{ha}^{-1}\right)$ & \multicolumn{1}{c}{$\mathrm{GA}_{3}$ application regimen } & Treated sweet orange cultivar \\
\hline GA-0 & 0 & None & Valencia and Navel \\
GA-30 & $25^{\mathrm{z}}$ & September, October, and November & Valencia \\
GA-40 & 25 & September, October, November, and December & Valencia \\
GA-50 & 25 & September, October, November, December, and January & Valencia \\
GA-60 & 49 & September, October, and November & Valencia \\
GA-80 & 49 & September, October, November, and December & Valencia \\
GA-100 & 49 & September, October, November, December, and January & Valencia and Navel \\
\hline${ }^{\mathrm{z}}$ Applications of $\mathrm{GA}_{3}$ at 25 and $49 \mathrm{~g} \cdot \mathrm{ha}^{-1}\left(10\right.$ and $20 \mathrm{~g} \cdot \mathrm{ac}^{-1}$, or $\approx 33$ and $17 \mathrm{mg} \cdot \mathrm{L}^{-1}$, respectively) refer to half- and full-strength rates, respectively, in \\
this study.
\end{tabular}

this research was therefore to shed light on the influences of exogenous $\mathrm{GA}_{3}$ on flowering in citrus trees affected by HLB.

The first objective of this study was to determine the timing and rate of $\mathrm{GA}_{3}$ treatments that effectively reduce and shorten citrus bloom under Florida conditions. Hence, foliar sprays of $\mathrm{GA}_{3}$ at two rates (25 and $49 \mathrm{~g} \cdot \mathrm{ha}^{-1}$, or 33 and $17 \mathrm{mg} \cdot \mathrm{L}^{-1}$, respectively) were made monthly starting in September, before the low temperatures that trigger floral induction (Krajewski and Rabe, 1995; Lord and Eckard, 1985, 1987; Nishikawa et al., 2009), and ended in November, December, or January (for a total of three, four, or five applications). Notably, all application regimens also overlapped the period of fall through early winter, during which off-season bloom usually happens (L. Tang and T. Vashisth, unpublished data). A subsidiary aim under the first research objective was to gain an understanding of the dynamic of endogenous GAs in relation to exogenous $\mathrm{GA}_{3}$ and flower development; thus, the concentration of GAs and relative expression of floral genes were analyzed in buds of 'Valencia' sweet orange trees with two extreme application regimens, that is, untreated control and applications of $\mathrm{GA}_{3}$ at $49 \mathrm{~g} \cdot \mathrm{ha}^{-1}$ from September through January. Because fruit (seeds), a source of endogenous $\mathrm{GA}_{3}$, act as a strong inhibitor of flowering (Iglesias et al., 2007; Monselise and Goldschmidt, 1982; Plummer et al., 1989; Talón et al., 1990), the second objective was to compare two sweet orange cultivars with different maturity times-earlymaturing Navel sweet orange harvested in November and late-maturing Valencia sweet orange harvested in April to May-in relation to the effects of exogenously supplied $\mathrm{GA}_{3}$. Although flowering in response to exogenous $\mathrm{GA}_{3}$ was the focus of the present report, the effects of $\mathrm{GA}_{3}$ treatments on fruit production as well as overall tree health in HLB-affected sweet orange trees were evaluated and are discussed in the second report by our group titled "Effects of Exogenous Gibberellic Acid in Huanglongbing-Affected Sweet Orange Trees under Florida Conditions - II. Fruit Production and Tree Health" (S. Singh, T. Livington, L. Tang, and T. Vashisth, unpublished data).

\section{Materials and Methods}

Plant materials and treatment conditions. Eight and 10-year-old 'Valencia' sweet orange on 'Swingle' citrumelo (Citrus paradisi $\times$ Poncirus trifoliata) rootstock and 18- and 15-year-old 'Navel' sweet orange on 'Swingle' citrumelo rootstock in commercial groves in Fort Meade (FM) and Haines City (HC), which are located on the central ridge Florida, were used. At each site, trees that were relatively uniform in height and canopy volume were selected. Due to the prevalence of HLB in Florida, citrus trees under open-air field conditions are rarely CLas-negative. All sweet orange trees in this research also exhibited HLB symptoms, including blotchy mottled leaves and branch dieback, indicating the state of being affected by the disease.

For 'Valencia' sweet orange, $\mathrm{GA}_{3}$ treatments were applied to the same trees for 3 consecutive years (2016-17, 2017-18, and 2018-19). The field experiment in FM and $\mathrm{HC}$ was laid out as a randomized complete block design. In each grove, there were four blocks (replications), each containing one untreated control and six $\mathrm{GA}_{3}$ treatments. Treatments included two rates of exogenous $\mathrm{GA}_{3}$, based on the existing literature on $\mathrm{GA}_{3}$ use in flowering research (reviewed by Garmendia et al., 2019), at three application regimens as follows: monthly foliar spray of $\mathrm{GA}_{3}$ at $20 \mathrm{~g} \cdot \mathrm{ac}^{-1}\left(49 \mathrm{~g} \cdot \mathrm{ha}^{-1}\right.$ or $\approx 33 \mathrm{mg} \cdot \mathrm{L}^{-1}$; "full-strength") from September to November (GA-60), from September to December (GA-80), and from September to January (GA-100); at $10 \mathrm{~g} \cdot \mathrm{ac}^{-1}\left(25 \mathrm{~g} \cdot \mathrm{ha}^{-1}\right.$ or $\approx 17$ $\mathrm{mg} \cdot \mathrm{L}^{-1}$; "half-strength") from September to November (GA-30), from September to December (GA-40), and from September to January (GA-50) (Table 1). The numbers in treatment names were assigned according to the combination (multiplication) of $\mathrm{GA}_{3}$ application rate $\left(20\right.$ or $\left.10 \mathrm{~g} \cdot \mathrm{ac}^{-1}\right)$ and total application times (three, four, or five applications) for easy adoption by citrus growers. For the application, $\mathrm{GA}_{3}$ (ProGibb LV Plus; Valent BioSciences, Libertyville, IL) mixed with $0.05 \%(\mathrm{v} / \mathrm{v})$ nonionic surfactant (Induce; Helena Chemical, Collierville, TN) was used. The control (GA- 0 ) trees were not treated with $\mathrm{GA}_{3}$ but sprayed with an equal amount of water containing surfactant as the $\mathrm{GA}_{3}$ treatments. All foliar applications were uniformly distributed to the canopy to the point of runoff $(\approx 4.7 \mathrm{~L}$ per tree) using a skid sprayer (Chemical Containers, Lake Wales, FL). Three consecutive trees were considered as one experimental unit but only the ones located in the center (one tree) in each unit were used for data and sample collection to allow sufficient buffer space between treatments.

The experiment was implemented for only 1 year (2018-19) for 'Navel' sweet orange trees in FM and $\mathrm{HC}$ groves with the same experimental design as for 'Valencia' sweet orange. However, only the GA-100 treatment was applied besides untreated control for 'Navel' sweet orange because of the limited number of trees with a similar level of HLB severity, based on the visual assessment, in the groves. Supplemental Figs. 1 and 2 depict the specific dates of $\mathrm{GA}_{3}$ applications for 'Valencia' sweet orange in 3 years (2016-17, 2017-18, 2018-19) and 'Navel' sweet orange trees in 2018-19. Monthly average maximum and minimum air temperatures for 2017-18 and 2018-19 (Supplemental Fig. 3) were downloaded from the Florida Automated Weather Station Network for the closest station to each grove.

Evaluation of flower bud emergence, bloom, and off-season flowering. The quantity of flower buds and open flowers was assessed in all treatments of the two cultivars and the two sites every 2 weeks from January through April (full bloom) using the method described by Cooper et al. (1963) and Hall and Albrigo (2007) with some modifications. Elongated flower buds [at the popcorn stage with elongated petals (Dewdney et al., 2019)] and open flowers were counted within a cubic square frame $(0.25 \times 0.25 \times 0.25 \mathrm{~m}, 15.63$ $\mathrm{dm}^{3}$ ), made of polyvinylchloride pipes, placed onto the outer tree canopy at the height of $\approx 1.5 \mathrm{~m}$ above the ground. For each tree, the results recorded from two frames on the east and west side of the canopy (two frames/tree) were averaged and reported herein. The number of total flower buds produced over the course of spring was calculated by adding up all flower bud numbers on individual survey days in each tree; the sum of flower buds was further used to calculate the cumulative sprouting rate of flower buds on each sampling day.

In the first year of the study (2016-17), 'Valencia' sweet orange trees at both sites were hedged in early March of 2017 by the growers, leading to the difficulty in accurately quantifying flower buds and open flowers thereafter even though those parameters were still recorded (Supplemental Fig. 4). Thus, to avoid any invalidity, the data collected in 2016-17 were not included in the analysis and discussion in the current study.

Young developing fruit (with transverse diameter $<4.0 \mathrm{~cm}$ ) were recorded using the cubic square frame method mentioned previously from January to February for 'Valencia' sweet orange and in December to 
February for 'Navel' sweet orange to represent the occurrence of off-season flowering that might have taken place in late fall or early winter. In addition, to assess whether PFD was affected by the $\mathrm{GA}_{3}$ applications, calyxes or buttons (where C. acutatum-caused fruitlet abscission takes place) were manually quantified on all trees after initial fruit set in subsequent June at both sites for two cultivars.

Sample collection and gene expression analysis. For 'Valencia' sweet orange located in FM in the 2018-19 experiment, 15 shoots with leaves were collected randomly from trees of the two extreme treatmentsuntreated control (GA-0) and GA-100 - on 13 Dec. 2018, and 11 Jan., 7 Feb., 18 Feb., 5 Mar., and 20 Mar. $2019(n=4)$. It should be noted that the samplings in December and January were done before the $\mathrm{GA}_{3}$ application in the corresponding months. After collection, the shoot tissues were quickly transferred to the laboratory on ice. Subsequently, leaves and buds were excised from the shoot, immediately frozen in liquid nitrogen, and stored at $-80^{\circ} \mathrm{C}$ in the freezer until further use.

Total RNA was extracted from $100 \mathrm{mg}$ of the leaf and bud tissue with the RNeasy Plant Mini Kit (Qiagen, Valencia, CA). After quality and quantity were validated using a spectrophotometer (Epoch 2 Microplate; BioTek Instruments, Winooski, VT) and denaturing formaldehyde $1.2 \%$ agarose gels (Rio, 2015), $1 \mu \mathrm{g}$ RNA was used for complementary DNA synthesis with DNase I (Promega, Madison, WI), oligo (dT) 15 primer, dNTP mix, and reverse transcriptase (ImProm-II; Promega) according to the manufacturers' protocols. Subsequently, expression levels of $F T$, apetalal (API), leafy ( $L F Y)$, and suppressor of overexpression of constans1 (SOC1), selected based on their roles in citrus flower development (Goldberg-Moeller et al., 2013; Sousa et al., 2019) (primer information listed in Supplemental Table 1), were determined using a real-time quantitative polymerase chain reaction (qPCR) system (7500 Fast Real-Time PCR System; Applied Biosystems, Foster City, CA). The qPCR reactions with dissociation-curve analysis, which confirmed that no nonspecific products were formed, were carried out following the procedures described by Tang and Vashisth (2020). Using the quantification cycle $(\mathrm{Ct})$, the levels of relative expression of genes of interest were expressed by the normalized relative quantity (NRQ) calculated with two reference genes, actin 7 and $\operatorname{dim} 1$ (Mafra et al., 2012, 2013), as internal control using the Pfaffl method (Hellemans et al., 2007; Pfaffl, 2001; Rieu and Powers, 2009) for visual presentation. For statistical analysis, $\log _{2}$ NRQ was used to account for heterogeneity of variance of the NRQ data based on Rieu and Powers (2009).

Analysis of endogenous gibberellic acids. For GA quantification, $100 \mathrm{mg}$ (fresh weight) of frozen bud tissues collected from 'Valencia' sweet orange trees in FM on 11 Dec. 2018, and 11 Jan. and 2 Feb. 2019 were sent to the Proteomics and Metabolomics Facility, Nebraska Center for Biotechnology,
University of Nebraska-Lincoln. Gibberellic acids, including $\mathrm{GA}_{1}, \mathrm{GA}_{3}, \mathrm{GA}_{4}, \mathrm{GA}_{8}, \mathrm{GA}_{9}$, $\mathrm{GA}_{12}, \mathrm{GA}_{19}, \mathrm{GA}_{20}, \mathrm{GA}_{24}, \mathrm{GA}_{29}$, and $\mathrm{GA}_{53}$, were extracted and analyzed using liquid chromatography-mass spectrometry targeted assay as described by Hung et al. (2016).

Statistical analysis. Statistical analyses were performed using $\mathrm{R}$ version 3.6.2 ( $\mathrm{R}$ Core Team, 2020) and SigmaPlot version 13 (Systat Software, San Jose, CA). Repeatedmeasures analysis of variance was used to determine the treatment effects on the number of total elongated flower buds and sprouting rate of flower buds (after arcsine square root transformation of the percentage data), followed by the Holm-Sidak method (at $P=$ 0.05 ) for post hoc mean separation at individual time points. Within the treatment, the number of open flowers on different days was compared using Dunnett's test, with first survey day as control; significant differences compared with the first day were noted as "pronounced flowering" dates in this study. Student's $t$ test was used to test for the difference in gene expression levels and $\mathrm{GA}_{3}$ concentrations in the GA- 0 and GA-100 'Valencia' sweet orange trees as well as the effects of GA-100 treatments on flowering parameters in 'Navel' sweet orange.

\section{Results}

Flower bud sprouting in 'Valencia' sweet orange. In 2018, the untreated control 'Valencia' sweet orange trees (GA-0) located in FM produced 234 (unopen) elongated flower buds per frame $(0.25 \times 0.25 \times 0.25 \mathrm{~m}$, $15.63 \mathrm{dm}^{3}$ ) in total in the spring (Fig. 1A). For the GA-0 trees, a substantial portion of flower buds (39\% of total) emerged on 12 Feb. (Fig. 1B, Supplemental Fig. 5A). Trees applied with full-strength $\mathrm{GA}_{3}$ monthly starting in September to November (GA-60), to December (GA-80), and to January (GA100) had 71, 62, and 65 flower buds per frame $(\leq 30 \%$ of the GA- 0 trees), respectively, over the course of the experiment, significantly fewer than that of the GA- 0 trees (Fig. 1A). When the concentration of $\mathrm{GA}_{3}$ was lowered by half, only the applications made in September to January (GA-50) resulted in a significant decrease in total flower buds per frame compared with the untreated control (Fig. 1A).

In 2019, for 'Valencia' sweet orange at the FM site, before most buds emerged on 7 Mar. ( $88 \%$ of total flower buds), a small quantity of flower buds sporadically sprouted on 5 and $18 \mathrm{Feb}$. (3\% and $18 \%$ of total flower buds, respectively) in GA-0 trees (Fig. 1D and Supplemental Fig. 5B), in contrast to the previous year. Despite lacking the significant reduction in the sum of flower buds in spring of 2019 (Fig. 1C), all $\mathrm{GA}_{3}$ treatments were able to hold off the bud emergence rate to less than $2 \%$ in February before the major sprouting in early March (Fig. 1D).

For 'Valencia' sweet orange grown in the $\mathrm{HC}$ grove, the three full-strength $\mathrm{GA}_{3}$ treatments significantly reduced the number of total flower buds per frame compared with the untreated control in 2018 (Fig. 1E), whereas monthly $\mathrm{GA}_{3}$ applications were only effective when made through January at either rate (GA-50 and GA-100) in 2019 (Fig. 1G). In both years, the GA-0 trees exhibited a pattern of sporadic bud sprouting in early spring $(21 \%$ of total flower buds on 13 Feb. 2018 and 7\% of total on 4 Feb. 2019) before the emergence of most buds in late February (Fig. 1F and H). In 2018, the sprouting rate of flower buds on 13 Feb. dropped to less than $3 \%$ in response to all $\mathrm{GA}_{3}$ treatments, significantly lower than that of the untreated control (Fig. 1F). In the following year, early bud emergence (on $4 \mathrm{Feb}$. 2019) was also brought down by all treatments, except GA-50, to merely $1 \%$ to $4 \%$ before the major sprouting (Fig. 1H), even though the difference was not statistically significant.

Temporal distribution and intensity of bloom in 'Valencia' sweet orange. In 2018, the first instance of open flowers was observed on 21 Feb. (eight flowers/frame) followed by the maximum bloom on 6 Mar. (23 flowers/frame) in the GA-0 'Valencia' sweet orange trees in FM (Fig. 2A); on both days, the number of open flowers was significantly greater than that of the first survey day (30 Jan.). Although flowering also occurred in the GA-0 trees on 21 Mar., the very few open flowers (two flowers/frame) was not different from the number on 30 Jan. Together, the results indicated that in the absence of exogenous GA, there were two dates of "pronounced flowering" for trees located in FM in 2018. In the spring following the treatments in 2018-19, the GA-0 trees also had two dates of pronounced flowering on 7 and 18 Mar. 2019 (Fig. 2B).

Two weeks before the maximum bloom in 2018 and 2019, the number of open flowers was decreased, either numerically or significantly, by all full-strength $\mathrm{GA}_{3}$ treatments $(<1$ and $<5$ flowers/frame on 21 Feb. 2018 and 7 Mar. 2019, respectively) compared with the GA-0 trees (Fig. 2A and B). As a result, the GA-60 and GA- 80 trees had only one date of pronounced flowering. Nevertheless, in either year, such a pattern of condensed bloom period was not observed in the GA-100 trees, which had two dates of pronounced flowering - on 6 and 21 Mar. 2018 and 18 Mar. and 2 Apr. 2019-demonstrating a delay in bloom. For the half-strength application regimens, both GA-40 and GA-50 reduced pronounced flowering to one date over the season in the FM grove for 2 continuous years (Fig. 2A and B).

For 'Valencia' sweet orange in $\mathrm{HC}$, the untreated control trees had only one date of pronounced flowering for 2 years in a row (Fig. 2C and D), in contrast to the extended spring bloom observed in trees in FM. Therefore, the effect of $\mathrm{GA}_{3}$ treatments on eliminating sporadic flowering before the peak bloom or on compressing the duration of bloom was unnoticeable in trees located in HC. It is noteworthy that, albeit not significantly different, the GA- 80 and GA-40 trees had fewer open flowers (fewer than one 

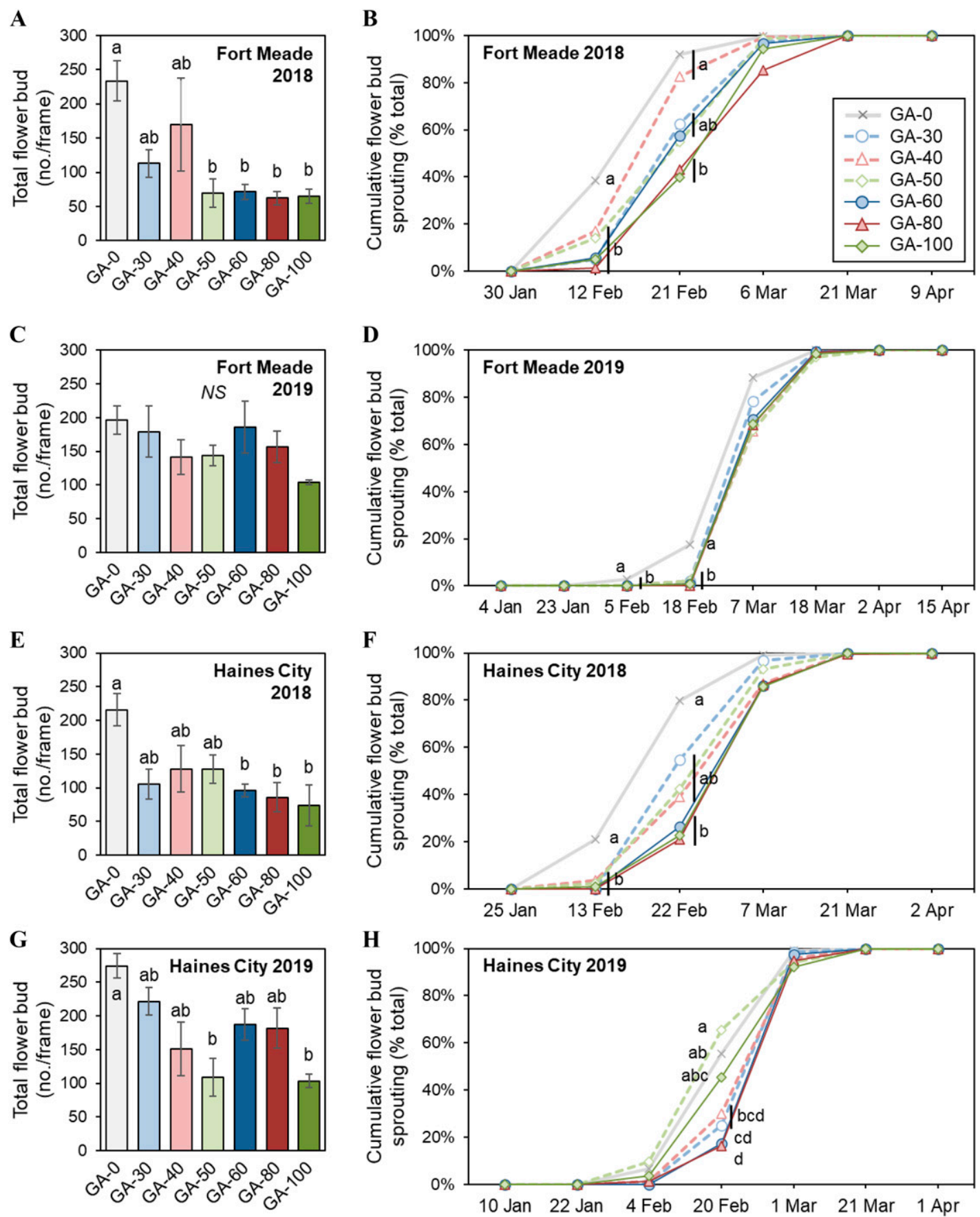

Fig. 1. Number of total elongated flower buds per frame produced in spring and cumulative rate of flower buds on individual survey days in untreated control (GA-0) 'Valencia' sweet orange trees and trees applied with gibberellic acid monthly from September to November, September to December, and September to January at the rate of 25 (GA-30, GA-40, and GA-50, respectively) and $49 \mathrm{~g} \cdot \mathrm{ha}^{-1}$ (GA-60, GA-80, and GA-100, respectively) in Fort Meade and Haines City in 2018 (A, B, E, F) and 2019 (C, D, G, H). Data are means \pm SD of four biological replicates. Within a column (day), means followed by the same letters are not significantly different $(P<0.05)$. NS = not significantly different.

flower/frame) than the GA-0 trees (eight flowers/frame) on 20 Feb. 2019, 2 weeks earlier than the maximum flowering.

Floral gene expression in buds and leaves of 'Valencia' sweet orange. Compared with the untreated control, the GA-100 treatments resulted in a decrease in floral intensity (the sum of flower buds and open flowers) on 5 Feb., 18 Feb., and 7 Mar. 2019 in 'Valencia' sweet orange trees grown in FM (Fig. 3A). After receiving $\mathrm{GA}_{3}$ sprays in September,
October, and November, the GA-100 trees had significantly lower transcript levels of $F T$ in leaves and $F T, L F Y$, and $A P l$ in buds than those of the GA-0 trees on 13 Dec. 2018, 2 months before the first significant decrease in floral intensity on 5 Feb. 2019 (Fig. 3B). The $\mathrm{GA}_{3}$ treatment continued to result in a significant reduction in $F T$ expression on 11 Jan. and 7 Feb. 2019, APl expression on 11 Jan. 2019, and $L F Y$ expression on 18 Feb. 2019 in buds compared with the untreated control.
There was no significant difference in bud SOC1 expression between the GA-100 and GA- 0 trees on any sampling day.

Endogenous gibberellic acid concentrations in buds of 'Valencia' sweet orange. Gibberellin acids in buds collected on 13 Dec. 2018, 11 Jan. 2019, and 2 Feb. 2019 from the GA-0 and GA-100 'Valencia' sweet trees grown in FM were analyzed. Across all sampling days, the concentrations of $\mathrm{GA}_{1}, \mathrm{GA}_{3}$, $\mathrm{GA}_{4} \mathrm{GA}_{8}, \mathrm{GA}_{12}, \mathrm{GA}_{19}, \mathrm{GA}_{20}, \mathrm{GA}_{24}$, and $\mathrm{GA}_{53}$ 
A

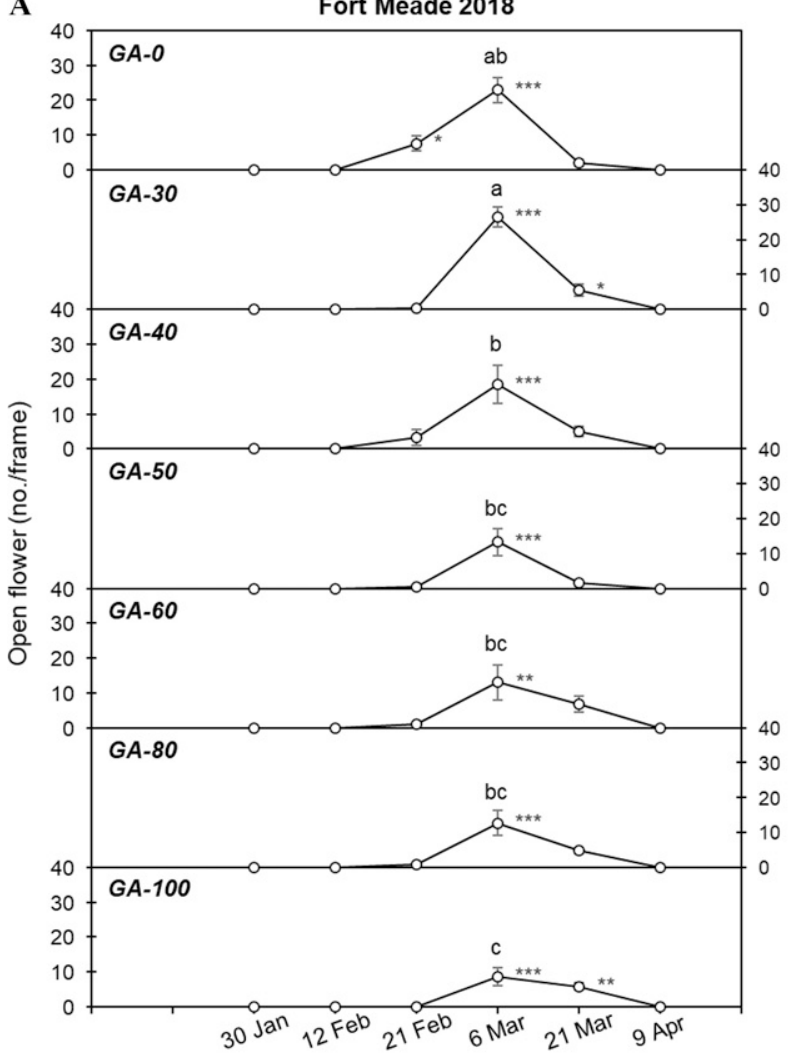

C

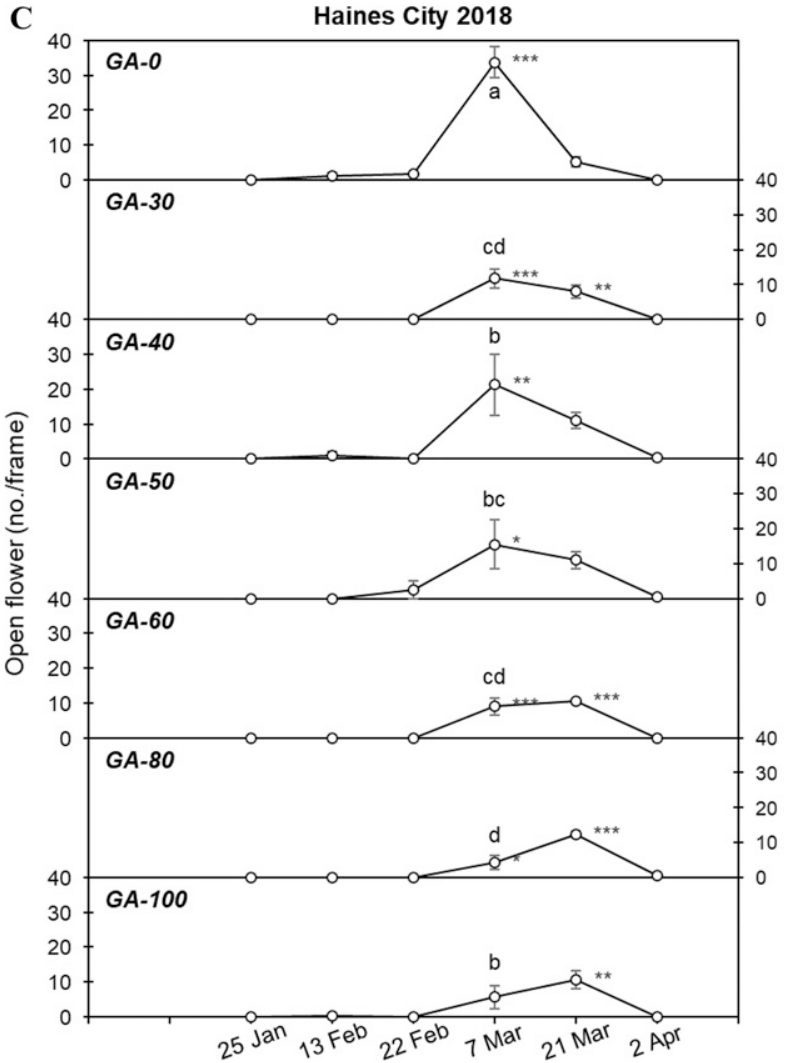

B

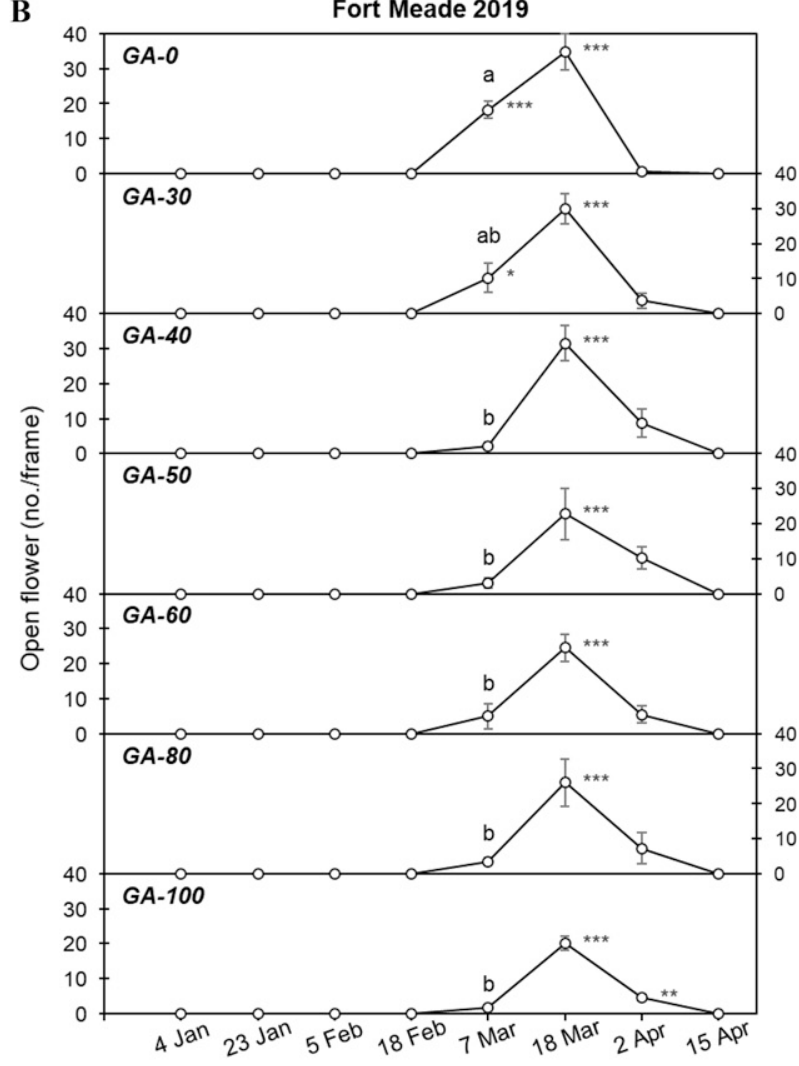

D

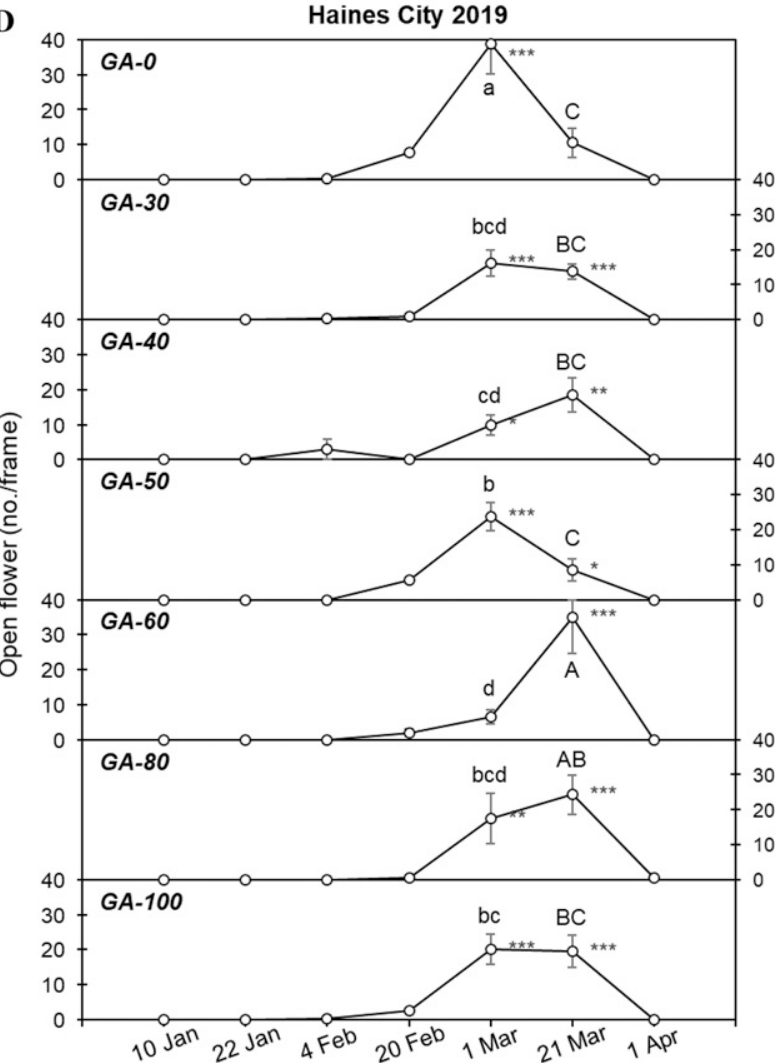

Fig. 2. Number of open flowers per frame in untreated control (GA-0) 'Valencia' sweet orange trees and trees applied with gibberellic acid monthly from September to November, September to December, and September to January at the rate of 25 (GA-30, GA-40, and GA-50, respectively) and 49 g-ha ${ }^{-1}$ (GA-60, GA-80, and GA-100, respectively) in Fort Meade in 2018 (A) and 2019 (B) and Haines City in 2018 (C) and 2019 (D). Data are means \pm SD of (continued) four biological replicates. Within each treatment, asterisks indicate significant difference compared with the number on the first survey day based on Dunnett's test. Within a column (day), means followed by the same lower or upper case letters are not significantly different $(P<0.05)$. Different letters indicate significant differences $(P<0.05)$ among treatments on the individual survey days. 


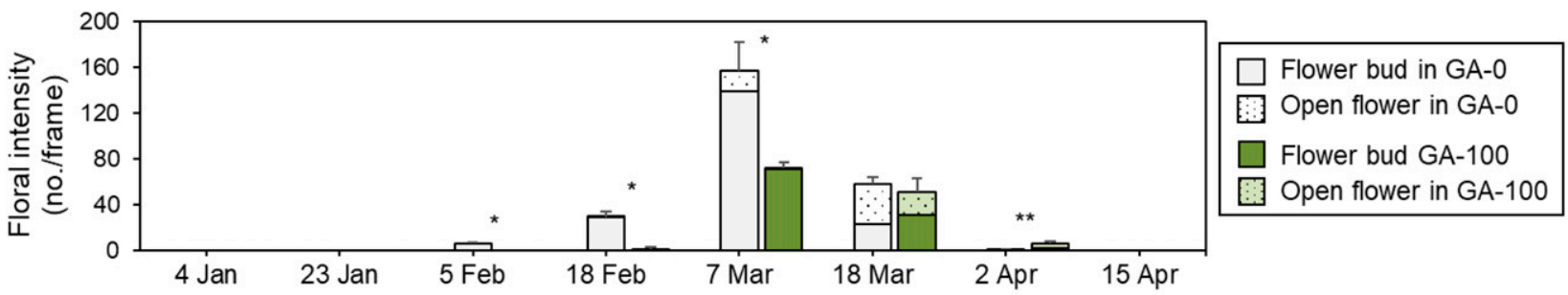

B
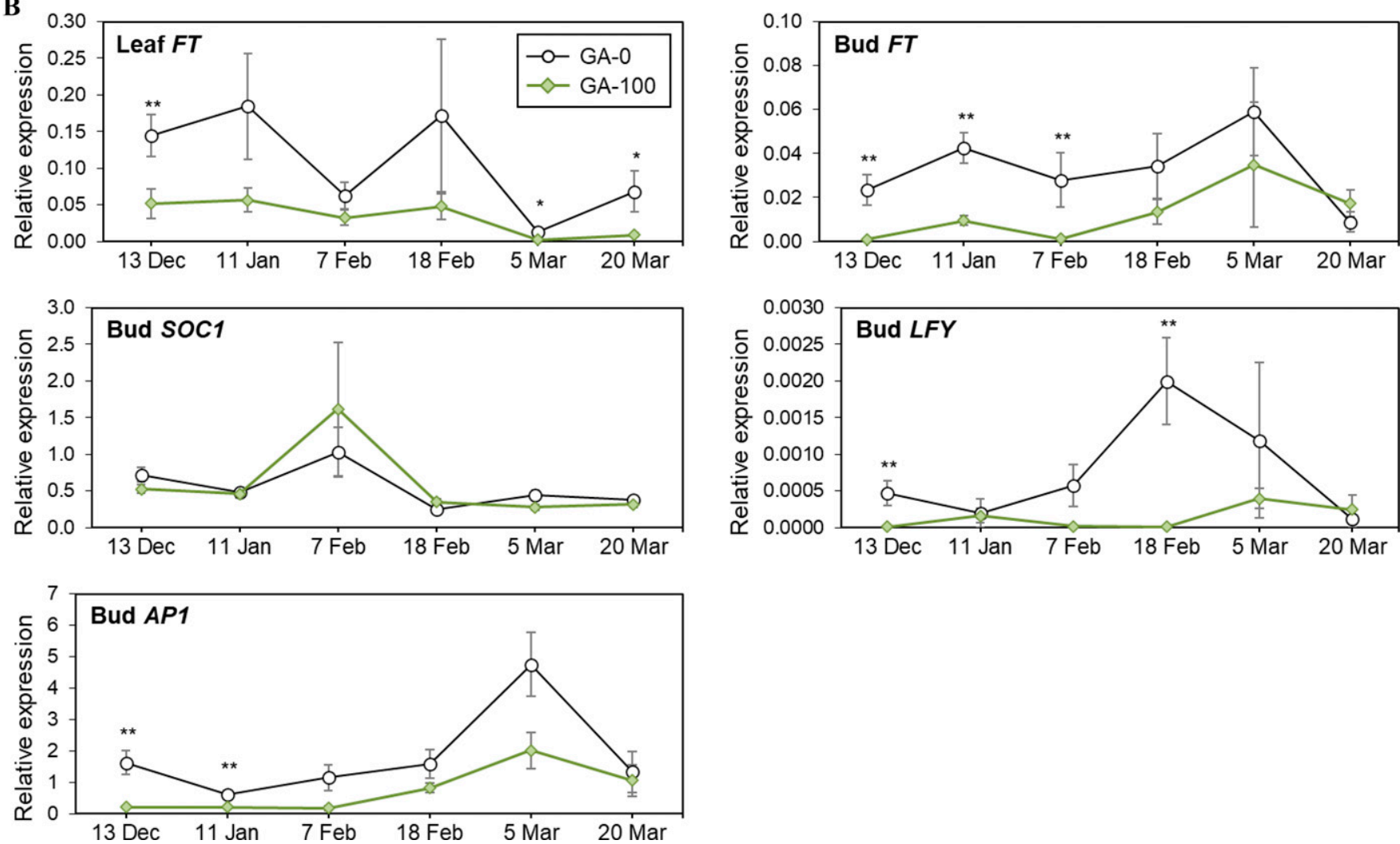

Fig. 3. Floral intensity, expressed as the sum of elongated flower buds and open flowers per frame, and the relative expression of flowering locus $t$ (FT), suppressor of overexpression of constans1 (SOCl), leafy ( $L F Y$ ), and apetalal (API) in untreated control (GA-0) 'Valencia' sweet orange trees and trees applied with $49 \mathrm{~g} \cdot \mathrm{ha}^{-1}$ gibberellic acid monthly from September to January (GA-100). Asterisks indicate significant differences between two treatments on individual sampling days.

were below the limit of detection in buds of the GA-0 and GA-100 trees (Table 2). Whereas $\mathrm{GA}_{9}$ was detected in buds of both treatments on all collection days, $\mathrm{GA}_{29}$ was detected only on 13 Dec. 2018 (Table 2). Nevertheless, there was no significant difference in the level of detected $\mathrm{GA}_{9}$ between the GA-0 and GA-100 treatments on any day. On the other hand, bud $\mathrm{GA}_{29}$ concentration in the GA-100 trees was significantly lower than that in the untreated control trees on 13 Dec. 2018, indicating that three monthly applications (made in September, October, and November) of full-strength $\mathrm{GA}_{3}$ might bring about a decrease in $\mathrm{GA}_{29}$ in the bud. In plants, $\mathrm{GA}_{29}$ could potentially compete with bioactive $\mathrm{GA}_{1}$ and inactive $\mathrm{GA}_{5}$, which can turn into either bioactive $\mathrm{GA}_{3}$ or inactive $\mathrm{GA}_{6}$, for the substrate $\mathrm{GA}_{20}$ (Sun, 2008). Therefore, whether bioactive GAs can be upregulated endogenously in citrus buds in response to exogenously applied $\mathrm{GA}_{3}$ remains inconclusive.

Flower bud sprouting in 'Navel' sweet orange. For 'Navel' sweet orange in FM, the GA-100 trees had 128 elongated flower buds cumulatively counted per frame over the course of spring in 2019, which was one-third fewer than the number of flower buds produced by the untreated control (GA-0) trees (192 flower buds), although not significantly $(P=0.07)$ (Fig. 4A). During the same year in $\mathrm{HC}$, the GA-100 treatment uniformly resulted in a significant decrease in total flower buds to 92 in spring, in comparison with 227 flower buds produced by the GA-0 trees (Fig. 4C).

In 2019, the GA-0 trees of 'Navel' sweet orange at $\mathrm{FM}$ and $\mathrm{HC}$ sites exhibited a pattern of scattered bud sprouting early in the season before a large population emerged on 5 Feb. ( $28 \%$ of total flower buds; Fig. 4B) and 4 Feb. ( $36 \%$ of total flower buds; Fig. 4D), respectively. To be specific, $5 \%$ and $11 \%$ of total flower buds emerged on 4 and 23 Jan., respectively, in the GA-0 trees in FM (Fig. 4B); for the untreated control trees in $\mathrm{HC}, 3 \%$ of total flower buds were observed on $10 \mathrm{Jan}$. and $12 \%$ on 22 Jan. (Fig. 4D). In parallel to the effect of $\mathrm{GA}_{3}$ treatments in 'Valencia' sweet orange, exogenous $\mathrm{GA}_{3}$ constantly reduced early bud sprouting to $2 \%$ on 4 Jan. and $4 \%$ on 23 Jan. in 'Navel' sweet orange trees in FM (Fig. 4B) and to less than $3 \%$ on 10 and 22 Jan. for trees in the HC grove (Fig. 4D).

Temporal distribution and intensity of bloom in 'Navel' sweet orange. For the GA-0 'Navel' sweet orange trees in FM, a small quantity of open flowers (fewer than five flowers/frame) were observed on 4 Jan., 23 Jan., and 5 Feb., followed by a substantial number of flowers on 19 Feb. (12 flowers/ frame), significantly greater than that of the first survey day in December of the previous year (Fig. 5A). On 8 and 18 Mar., the number of open flowers remained remarkedly greater than the first day, leading to a total of three dates of pronounced flowering in spring for the untreated control 'Navel' sweet orange trees. Monthly applications of full-strength $\mathrm{GA}_{3}$ from September to January effectively reduced the number of open flowers on 5 Feb., 19 Feb., and 8 Mar. (fewer than five flowers/frame) compared with the GA-0 
Table 2. Concentrations of gibberellic acids (GAs) in buds of untreated control (GA-0) 'Valencia' sweet orange trees and trees applied with $49 \mathrm{~g} \cdot \mathrm{ha}^{-1} \mathrm{GA}$ monthly from September to January (GA-100).

\begin{tabular}{llcccc}
\hline & & \multicolumn{3}{c}{$\mathrm{GA}^{\mathrm{z}}$ concn $\left(\mathrm{ng} \cdot \mathrm{g}^{-1}\right)$} \\
\cline { 3 - 5 } Date & Treatment & $\mathrm{GA}_{9}$ & $P$ value & $\mathrm{GA}_{29}$ & $P$ value \\
\hline 13 Dec. 2018 & GA-0 & $1109^{\mathrm{x}}$ & 0.647 & 209 & 0.001 \\
& GA-100 & 1279 & & 136 & na \\
11 Jan. 2019 & GA-0 & 879 & 0.051 & $\mathrm{ND}$ & na \\
& GA-100 & 1376 & & $\mathrm{ND}$ & $\mathrm{ND}$ \\
\end{tabular}

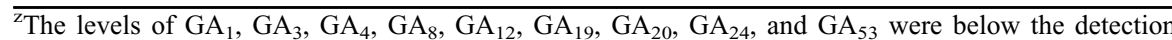
limit and therefore not presented in this table.

${ }^{\mathrm{y}}$ Treatment effects on individual days are determined using Student's $t$ test.

${ }^{\mathrm{x}}$ Data are means of four biological replicates; ND $=$ not detected; na $=$ not available.

trees, albeit not statistically significant on 8 Mar., leaving only one date of pronounced flowering for the GA-100 trees of 'Navel' sweet orange on 18 Mar. (Fig. 5A). Similarly, the GA-100 trees in HC produced significantly fewer open flowers on $20 \mathrm{Feb}$. and 4 Mar. compared with the untreated control, and had one sole date of pronounced flowering in spring (Fig. 5B).

Off-season bloom 'Valencia' and 'Navel' sweet orange. In this research, young developing fruit (with transverse diameter $<4.0$ $\mathrm{cm}$ ) were quantified up until early February to represent the occurrence of off-season flowering that might take place in late fall or early winter in Florida. For 'Valencia' sweet orange, zero fruit was recorded during the period of January through February for the GA-0 trees, and those subjected to any of the treatments grown at both sites across years. In contrast, a small number of developing fruit (fewer than eight fruit/frame) was observed in the GA-0 trees of 'Navel' sweet orange in $\mathrm{FM}$ and $\mathrm{HC}$ in the beginning of January (Fig. 6). The fruit number in the GA100 trees, nonetheless, was not significantly less than that of the control on any sampling day, indicating the incidence of off-season flowering might not be vastly different between the two.

PFD in 'Valencia' and 'Navel' sweet orange. For sweet orange trees of all treatments (including non- $\mathrm{GA}_{3}$-treated control) in this research, the number of buttons per frame was always less than 10 in June (after initial fruit set) 2017, 2018, and 2019 (data not shown), indicating PFD outbreak did not occur in either grove when the current study was conducted. It should be noted that there was also no report of severe PFD outbreak during those years (Summer 2017-19) for other locations in Florida.

\section{Discussion}

The results reported herein demonstrate distinctions in the flowering behavior between HLB-affected 'Valencia' and 'Navel' sweet orange under field conditions. In the absence of exogenous GA, the trend of off-season bloom, estimated using the number of developing fruit (zero fruit for all cases), was not apparent in 'Valencia' sweet orange trees at either site for 2 consecutive years. In contrast, the observation of small fruit on non-GAtreated 'Navel' sweet orange trees as early as January indicated that a few flowers were produced in November or early December the previous year (Fig. 6). The obvious pattern of off-season flowering in 'Navel' sweet orange may be attributed to the relatively short duration of fruit present on trees. In this study, Navel, an early-maturing cultivar, was harvested in November, which coincided with the estimated time of off-season bloom, whereas harvests of late-maturing 'Valencia' sweet orange did not happen until the following April to May (Supplemental Figs. 1 and 2).
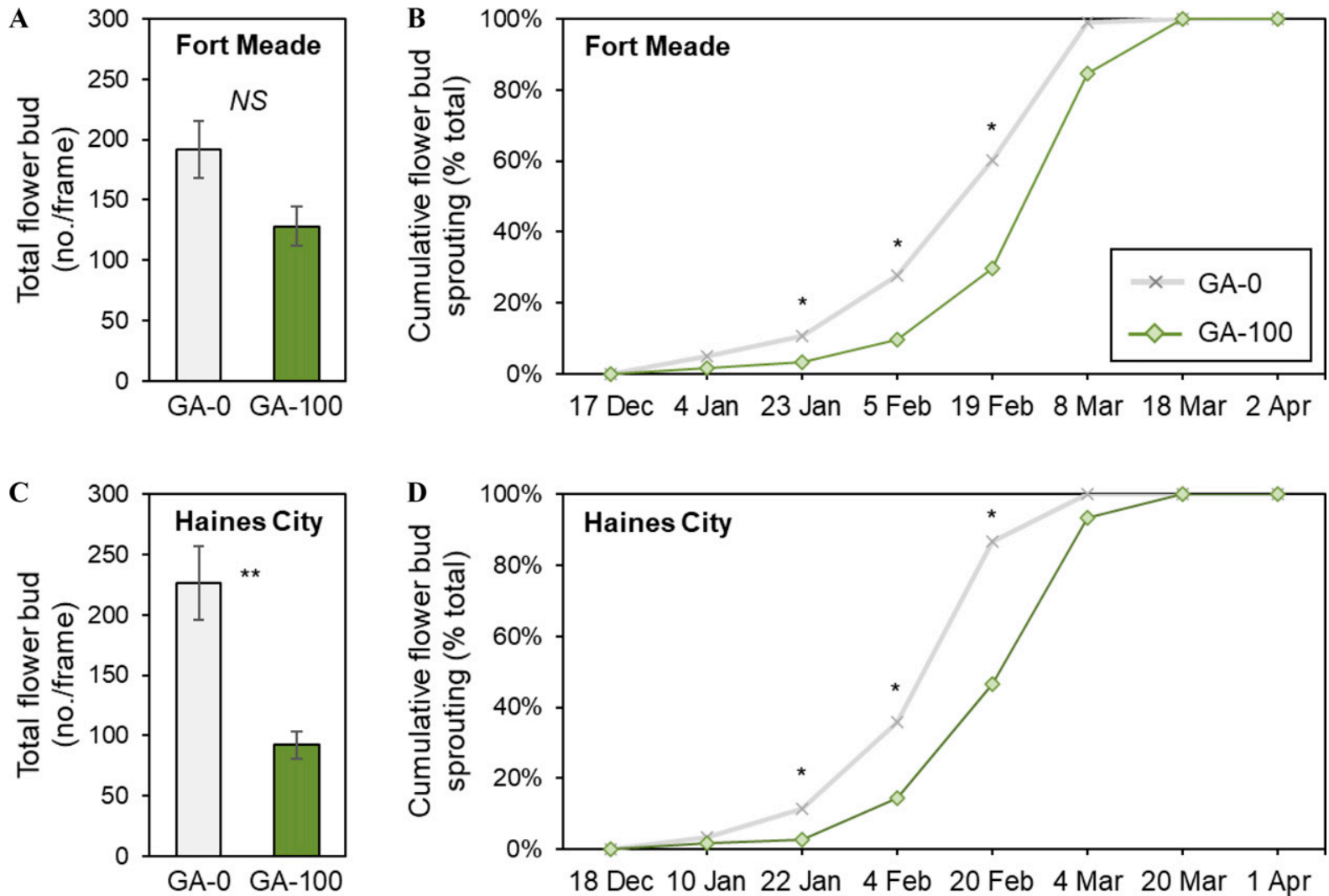

Fig. 4. Number of total elongated flower buds per frame produced in spring and cumulative rate of flower buds on individual survey days in untreated control (GA-0) 'Navel' sweet orange trees and trees applied with gibberellic acid monthly from September to January at the rate of $49{\mathrm{~g} \cdot h{ }^{-1}}^{-1 G A-100)}$ in Fort Meade (A, B) and Haines City $(\mathbf{C}, \mathbf{D})$. Data are means $\pm \mathrm{SD}$ of four biological replicates. Asterisks indicate significant differences between two treatments. $N S=$ not significantly different. 
A

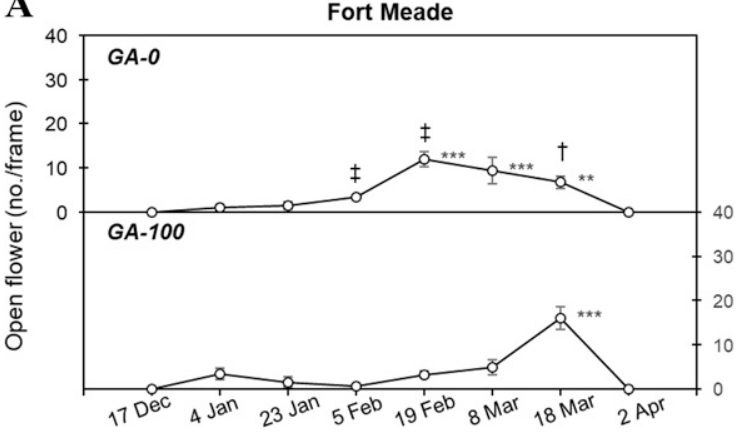

B

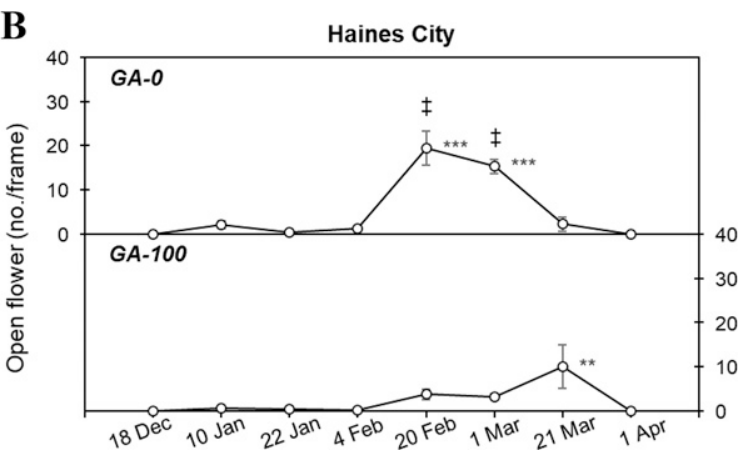

Fig. 5. Number of open flowers per frame in untreated control (GA-0) 'Navel' sweet orange trees and trees applied with gibberellic acid monthly from September to January at the rate of $49 \mathrm{~g} \cdot \mathrm{ha}^{-1}$ (GA-100) in Fort Meade (A) and Haines City (B). Within each treatment, asterisks indicate significant difference compared with the number on the first survey day based on Dunnett's test. Daggers and double daggers indicate significant differences of two treatments at $P<0.05$ and 0.01 , respectively.

It is relevant that fruit collectively act as a strong inhibitor of flower development in citrus (Garcia-Luis et al., 1986; Martínez-Fuentes et al., 2010; Monselise and Goldschmidt, 1982; Shalom et al., 2012). In addition, limited rainfall during the Florida dry season in fall likely subjects HLB-affected citrus trees with already compromised root systems to waterdeficit stress (Hamido et al., 2017; Johnson et al., 2014), which triggers flowering (Chica and Albrigo, 2013; Lovatt et al., 1988; Southwick and Davenport, 1986), especially when the floral inhibitor (fruit) is not present, leading to off-season bloom. 'Navel' sweet orange also had flower buds sprouting earlier (in January) (Fig. 4) with more extended period of flowering the following spring (two to three dates of pronounced flowering) (Fig. 5) compared with 'Valencia' sweet orange, for which the emergence of elongated buds began in February and there were only one or two dates of pronounced flowering (Figs. 1 and 2). These observations suggest that the inherent factors within cultivars that regulate fruit maturity, which affects the harvest time, play an essential role on phenology of return flowering in citrus trees.

Monthly application of full-strength $\mathrm{GA}_{3}$ (49 $g \cdot h^{-1}$ ) starting at September through January had no noticeable effect on eliminating off-season flowering occurring in November or December for 'Navel' sweet orange at either site (Fig. 6), suggesting that the combined influence of fruit removal (harvest) and ambient floral-inductive conditions on promoting flowering negated the inhibition exerted by the exogenous $\mathrm{GA}_{3}$ sprays. Therefore, to minimize the presence of off-season bloom in 'Navel' sweet orange or early-maturing cultivars, the efficacy of more frequent $\mathrm{GA}_{3}$ applications and/or at a higher rate on incidental flowering in fall and early winter awaits evaluation.

On the other hand, even though zero developing fruit was present on the canopy of 'Valencia' sweet orange trees from January to February in the current study, this result does not preclude the possible occurrence of flowers produced before the evaluation day. Instead, this may reflect the erratic nature of off-season bloom for field-grown HLB-affected citrus trees in Florida because the behavior of scattered flowering during late fall or early winter has been commonly observed in this cultivar (L. Tang and T. Vashisth, unpublished data).

With the exception of trees in FM in 2018 (Fig. 1B), all untreated control trees of 'Valencia' sweet orange had a small percentage of elongated flower buds growing out before the major sprouting (Fig. 1D, F, and H). The results reported herein demonstrated that such a pattern of sporadic flower bud spouting can be markedly reduced in response to any $\mathrm{GA}_{3}$ treatments excluding GA-50 treatment, which resulted in a greater sprouting rate than the control in $\mathrm{HC}$ on 2 Feb. 2019. Interestingly, GA60 , GA-80, and GA-100 trees produced a similar amount of total flower buds in each year and location (Fig. 1A, C, E, and G), despite receiving different numbers of $\mathrm{GA}_{3}$ applications. The results suggest that the effect of exogenous $\mathrm{GA}_{3}$ is not additive, with extra applications carried out after December. In sweet orange, exogenous $\mathrm{GA}_{3}$ inhibits flowering by promoting the vegetative development of shoot apical meristems when applied before buds become determined, or irreversibly committed to flower development (Lord and Eckard, 1987). Lord and Eckard (1987) also documented that after the initiation of the first sepal in the terminal meristem in early January, exogenously applied $\mathrm{GA}_{3}$ had no influence on suppressing citrus flower formation anymore. Undoubtedly, the time of bud determinacy-a meristem development stage after which exogenous $\mathrm{GA}_{3}$ no longer inhibits citrus flowering - may vary in trees of different studies due to the differences in climatic conditions, especially air temperatures and occurrence of drought stress (Chica and Albrigo, 2013; Tang and Lovatt, 2019). Nevertheless, the results of recent studies demonstrated that in the subtropics of the Northern Hemisphere, applying $\mathrm{GA}_{3}$ once in early December or four times from mid-November through mid-December (at 2-
A

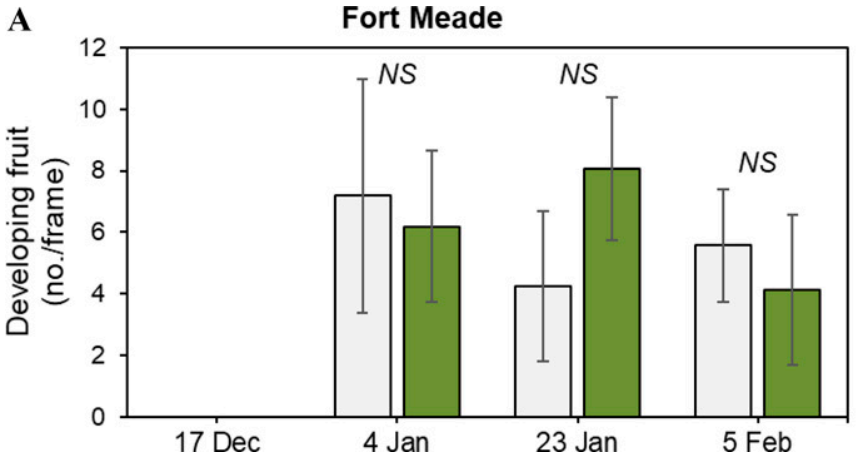

B

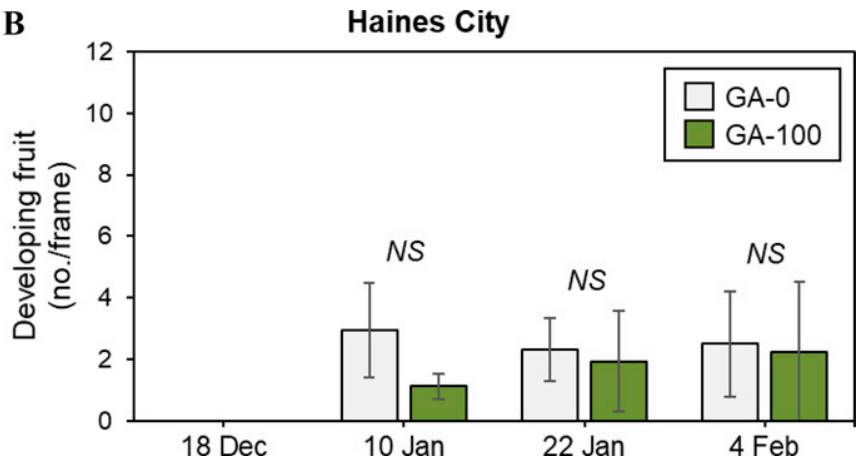

Fig. 6. Number of developing fruit (with transverse diameter $<4.0 \mathrm{~cm}$ ) per frame in untreated control $(\mathrm{GA}-0)$ 'Navel' sweet orange trees and trees applied with gibberellic acid monthly from September to January at the rate of $49 \mathrm{~g} \cdot \mathrm{ha}^{-1}$ (GA-100) in Fort Meade (A) and Haines City (B). Data are means \pm SD of four biological replicates. $N S=$ not significantly different. 
week intervals) was sufficient to significantly reduce flower intensity at full bloom in healthy field-grown citrus trees (Goldberg-Moeller et al., 2013; Muñoz-Fambuena et al., 2012). Taken together, the observations of the current research suggest that the effect of exogenous $\mathrm{GA}_{3}$ on flower suppression may become negligible when the monthly applications were made through January under Florida conditions in comparison with the regimen ended by November or December. This inference is in agreement with the results of gene expression analysis in the GA-100 and GA-0 trees of 'Valencia' sweet orange. Compared with the untreated control, downregulation of FT transcripts in leaves and $F T, A P 1$, and $L F Y$ expression in buds of the GA-100 trees took place as early as 13 Dec. 2018, following three monthly applications of $\mathrm{GA}_{3}$ at the full strength from September to November (Fig. 3B). In citrus, $F T, A P 1$ and $L F Y$ act as the positive regulator in citrus flower development (Endo et al., 2005; Pillitteri et al., 2004), analogous to their homologs in Arabidopsis thaliana (Bowman et al., 1991; Corbesier et al., 2007; Kinoshita and Richter, 2020; Weigel et al., 1992). Further, their expression levels were strongly correlated with the number of inflorescences in field-grown healthy citrus trees in response to inductive conditions, such as fruit removal and seasonal low temperatures (Nishikawa et al., 2009; Shalom et al., 2014), as well as floral inhibitor $\mathrm{GA}_{3}$ (Goldberg-Moeller et al., 2013; Muñoz-Fambuena et al., 2012). In this study, the expression of $\mathrm{SOCl}$ in buds was not responsive to exogenous $\mathrm{GA}_{3}$ on any collection day, similar to the results documented by Goldberg-Moeller et al. (2013) and Muñoz-Fambuena et al. (2012), providing evidence that the $\mathrm{GA}_{3}$-induced downregulation of citrus flower development may not be mediated via the transcription of SOCl.

Regardless of the application regimen, the effect of the $\mathrm{GA}_{3}$ treatments at the full strength on repressing 'Valencia' flower bud formation, represented by the total number of flower buds produced in spring, was more prominent compared with their half-strength $\left(25 \mathrm{~g} \cdot \mathrm{ha}^{-1}\right)$ counterparts at both sites in 2018 (Fig. 1A and E), although the trend was inconsistent the following year (Fig. 1C and G). The discrepancy between the years might be due to the slightly greater maximum temperatures during January and February in 2019 than 2018 (Supplemental Fig. 3), which favored the development of flower buds (Albrigo, 2004; Valiente and Albrigo, 2002) and thus prevailed over the inhibitory effect exerted by exogenous $\mathrm{GA}_{3}$ to some degree.

For 'Valencia' sweet orange, the GA-80 treatment consistently reduced the number of open flowers before the major bloom, minimizing sporadic flowering early in the season. In addition, the duration of spring bloom, indicated by the number of dates of pronounced flowering compared with the first survey day, was shortened in the GA- 80 trees compared with the GA- 0 trees for 2 consecutive years in FM (Fig. 2A and B). Although such a treatment effect on reducing bloom period was not observed for the GA- 80 trees in the $\mathrm{HC}$ grove in either year (Fig. 2C and $\mathrm{D})$, it is notable that the duration of spring flowering for the untreated control trees in $\mathrm{HC}$ was not as extended (with only one pronounced flowering date) as for those in FM (having two dates of pronounced flowering). Thus, it is possible that the responses to exogenous $\mathrm{GA}_{3}$ might be masked by the relatively brief period of seasonal bloom in 'Valencia' sweet orange trees in HC. The results also indicated that despite being the same cultivar and under presumably similar climatic conditions (Supplemental Fig. 3), given the close proximity between the FM and $\mathrm{HC}$ groves ( $<50 \mathrm{~km}$ apart), the duration of flowering differs for citrus trees affected by HLB.

For 'Navel' sweet orange, the sole $\mathrm{GA}_{3}$ treatment in this study, GA-100, resulted in a decrease in the emergence of flower buds and open flowers before the peak bloom and thereby compressed the bloom period in spring, analogous to the effects of the GA-80 treatment in 'Valencia' sweet orange. Nevertheless, whether a regimen with fewer $\mathrm{GA}_{3}$ applications, GA-80 for example, would cause similar results awaits determination for this early-maturing cultivar.

By reducing the duration and intensity of bloom, GA-80 and GA-100 treatments might be used to limit the buildup of pathogens that infect flowers in 'Valencia' and 'Navel' sweet orange, respectively, under Florida conditions. In the case of PFD caused by $C$. acutatum, outbreak did not occur in either grove when this study was conducted. It should be noted that severe outbreak of PFD takes place only when the environmental conditions in spring are favorable for fungal distribution (i.e., warm temperatures with wetness in the presence of flowers) (Dewdney, 2017; Peres et al., 2002, 2005; Perondi et al., 2020). Thus, as the results reported herein do not indicate or negate the efficacy of $\mathrm{GA}_{3}$ in PFD control, the effect of altered flowering patterns by exogenous $\mathrm{GA}_{3}$ on $C$. acutatum proliferation needs to be further examined. Moreover, flowering manipulation with $\mathrm{GA}_{3}$ may bring supplemental advantage to the vector control of HLB. At present, most insecticides targeting asian citrus psyllid (Diaphorina citri), the insect vector that transmits the pathogen that causes HLB (Halbert et al., 2000; Jagoueix et al., 1994), are also toxic to bees, so their uses are not recommended when citrus trees are flowering (Stansly et al., 2019). Hence, the absence of scattered and prolonged flowering ahead of full bloom in GA-treated trees might allow an extended application regimen of insecticides to diminish psyllid population for a more extensive HLB control compared with trees with an irregular flowering pattern.

\section{Conclusions}

This research, for the first time, documented the seasonal flowering pattern (i.e., emergence of flower buds and open flowers from January through April), with a quantitative approach in two sweet orange cultivars affected by HLB. The results reported herein further demonstrated that monthly applications of full-strength $\mathrm{GA}_{3}\left(49 \mathrm{~g} \cdot \mathrm{ha}^{-1}\right)$ from September through December (GA-80) and from September to January (GA-100) are the most effective and consistent treatments to manipulate spring flowering in HLB-affected 'Valencia' and 'Navel' sweet orange, respectively. Specifically, the two $\mathrm{GA}_{3}$ treatments minimized the presence of elongated buds and open flowers before the peak bloom and shortened the length of spring flowering. Thus, with its efficacy to modulate irregular flowering under Florida climate conditions in the presence of HLB, whether exogenous $\mathrm{GA}_{3}$ further shortens the infection window of flower-targeting pathogens and enhances disease prevention awaits determination.

\section{Literature Cited}

Agostini, J.P., T.R. Gottwald, and L.W. Timmer. 1993. Temporal and spatial dynamics of postbloom fruit drop of citrus in Florida. Phytopathology 83:485-490, https://doi.org/10.1094/ Phyto-83-485.

Albrigo, L.G. 2004. Climatic effects on flowering, fruit set and quality of citrus - A review. Proc. Intl. Soc. Citricult. X Congr. 278-283.

Bowman, J.L., D.R. Smyth, and E.M. Meyerowitz. 1991. Genetic interactions among floral homeotic genes of Arabidopsis. Development 112: 1-20, https://doi.org/10.1242/dev.112.1.1.

Chica, E.J. and L.G. Albrigo. 2013. Expression of flower promoting genes in sweet orange during floral inductive water deficits. J. Amer. Soc. Hort. Sci. 138:88-94, https://doi.org/10.21273/ JASHS.138.2.88.

Cooper, W.C., A. Peynado, J.R. Furr, R.H. Hilgeman, G.A. Cahoon, and S.B. Boswell. 1963. Tree growth and fruit quality of Valencia oranges in relation to climate. Proc. Amer. Soc. Hort. Sci. 82:180-192.

Corbesier, L., C. Vincent, S. Jang, F. Fornara, Q. Fan, I. Searle, A. Giakountis, S. Farrona, L. Gissot, C. Turnbull, and G. Coupland. 2007. FT protein movement contributes to long-distance signaling in floral induction of Arabidopsis. Science 316:1030-1033, https://doi.org/ 10.1126/science. 1141752

Dewdney, M.M. 2015. Postbloom fruit drop: Spring is coming. Citrus Ind. 96(11):12-15.

Dewdney, M.M. 2017. Will you be ready for postbloom fruit drop? Citrus Ind. 98(1):14-20.

Dewdney, M.M. and J.H. Graham. 2016. Foliar disease management in 2016. Citrus Ind 97(3):24-27.

Dewdney, M.M., N.A. Peres, and J.D. Burrow. 2019. Postbloom fruit drop (PFD) identification and management. Univ. Florida, Inst. Food Agr. Sci. Ext. Gainesville, FL. 15 Mar. 2020. $<$ https://edis.ifas.ufl.edu/pp318>

Endo, T., T. Shimada, H. Fujii, Y. Kobayashi, T. Araki, and M. Omura. 2005. Ectopic expression of an $F T$ homolog from citrus confers an early flowering phenotype on trifoliate orange (Poncirus trifoliata L. Raf.). Transgenic Res. 14:703-712, https://doi.org/10.1007/s11248-005-6632-3.

Garcia-Luis, A., V. Almela, C. Monerri, M. Agustí, and J.L. Guardiola. 1986. Inhibition of flowering in vivo by existing fruits and applied growth regulators in Citrus unshiu. Physiol. Plant. 66:515-520, https://doi.org/ 10.1111/j.1399-3054.1986.tb05960.x.

Garmendia, A., R. Beltrán, C. Zornoza, F.J. GarcíaBreijo, J. Reig, and H. Merle. 2019. Gibberellic acid in Citrus spp. flowering and fruiting: A 
systematic review. PLoS One 14:e0223147, https://doi.org/10.1371/journal.pone.0223147.

Goldberg-Moeller, R., L. Shalom, L. Shlizerman, S. Samuels, N. Zur, R. Ophir, E. Blumwald, and A. Sadka. 2013. Effects of gibberellin treatment during flowering induction period on global gene expression and the transcription of flowering-control genes in Citrus buds. Plant Sci. 198:46-57, https://doi.org/10.1016/j.plantsci.2012.09.012.

Graham, J.H., E.G. Johnson, T.R. Gottwald, and M.S. Irey. 2013. Presymptomatic fibrous root decline in citrus trees caused by Huanglongbing and potential interaction with Phytophthora spp. Plant Dis. 97:1195-1199, https://doi.org/ 10.1094/PDIS-01-13-0024-RE.

Halbert, S.E., C.L. Niblett, K.L. Manjunath, R.F. Lee, and L.G. Brown. 2000. Establishment of two new vectors of citrus pathogens in Florida. Proc. Intl. Soc. Citricult. IX Congr. 1016-1017.

Hall, D.G. and L.G. Albrigo. 2007. Estimating the relative abundance of flush shoots in citrus with implications on monitoring insects associated with flush. HortScience 42:364-368, https:// doi.org/10.21273/HORTSCI.42.2.364.

Hamido, S.A., K.T. Morgan, and D.M. Kadyampakeni. 2017. The effect of Huanglongbing on young citrus tree water use. HortTechnology 27:659-665, https://doi.org/10.21273/HORTTECH03830-17.

Hellemans, J., G. Mortier, A. De Paepe, F. Speleman, and J. Vandesompele. 2007. qBase relative quantification framework and software for management and automated analysis of real-time quantitative PCR data. Genome Biol. 8:R19, https://doi.org/10.1186/gb-2007-8-2-r19.

Hung, C.Y., J. Qiu, Y.H. Sun, J. Chen, F.S. Kittur, R.J. Henny, G. Jin, L. Fan, and J. Xie. 2016. Gibberellin deficiency is responsible for shyflowering nature of Epipremnum aureum. Sci. Rep. 6:28598, https://doi.org/10.1038/srep28598.

Iglesias, D.J., M. Cercós, J.M. Colmenero-Flores, M.A. Naranjo, G. Ríos, E. Carrera, O. RuizRivero, I. Lliso, R. Morillon, F.R. Tadeo, and M. Talon. 2007. Physiology of citrus fruiting. Braz. J. Plant Physiol. 19:333-362, https:// doi.org/10.1590/S1677-04202007000400006.

Jagoueix, S., J.-M. Bové, and M. Garnier. 1994. The phloem-limited bacterium of greening disease of citrus is a member of the $\alpha$ subdivision of the proteobacteria. Intl. J. Syst. Bacteriol. 44:379-386, https://doi.org/10.1099/0020771344-3-379.

Johnson, E.G., J. Wu, D.B. Bright, and J.H. Graham. 2014. Association of 'Candidatus Liberibacter asiaticus' root infection, but not phloem plugging with root loss on Huanglongbingaffected trees prior to appearance of foliar symptoms. Plant Pathol. 63:290-298, https:// doi.org/10.1111/ppa.12109.

Kinoshita, A. and R. Richter. 2020. Genetic and molecular basis of floral induction in Arabidopsis thaliana. J. Expt. Bot. 71:2490-2504, https://doi.org/10.1093/jxb/eraa057.

Krajewski, A.J. and E. Rabe. 1995. Citrus flowering: A critical evaluation. J. Hort. Sci. 70:357-374, https://doi.org/10.1080/14620316.1995.11515306.

Lord, E.M. and K.J. Eckard. 1985. Shoot development in Citrus sinensis L. (Washington navel orange). I. Floral and inflorescence ontogeny. Bot. Gaz. 146:320-326, https://doi.org/10.1086/ 337531.

Lord, E.M. and K.J. Eckard. 1987. Shoot development in Citrus sinensis L. (Washington navel orange). II. Alteration of developmental fate of flowering shoots after $\mathrm{GA}_{3}$ treatment. Bot. Gaz. 148:17-22, https://doi.org/10.1086/337623.

Lovatt, C.J., Y. Zheng, and C.D. Hake. 1988. Demonstration of a change in nitrogen metabolism influencing flower initiation in Citrus. Isr. J. Bot. 37:181-188.

Mafra, V., K.S. Kubo, M. Alves-Ferreira, M Ribeiro-Alves, R.M. Stuart, L.P. Boava, C.M. Rodrigues, and M.A. Machado. 2012. Reference genes for accurate transcript normalization in citrus genotypes under different experimental conditions. PLoS One 7:e31263, https:// doi.org/10.1371/journal.pone.0031263.

Mafra, V., P.K. Martins, C.S. Francisco, M. Ribeiro-Alves, J. Freitas-Astúa, and M.A. Machado. 2013. Candidatus Liberibacter americanus induces significant reprogramming of the transcriptome of the susceptible citrus genotype. BMC Genomics 14:247, https:// doi.org/10.1186/1471-2164-14-247.

Martínez-Fuentes, A., C. Mesejo, C. Reig, and M. Agustí. 2010. Timing of the inhibitory effect of fruit on return bloom of "Valencia" sweet orange (Citrus sinensis (L.) Osbeck). J. Sci. Food Agr. 90:1936-1943, https://doi.org/ 10.1002/jsfa.4038.

Monselise, S.P. and E.E. Goldschmidt. 1982. Alternate bearing in fruit trees. Hort. Rev. (Amer. Soc. Hort. Sci.) 4:128-173.

Muñoz-Fambuena, N., C. Mesejo, M.C. GonzálezMas, D.J. Iglesias, E. Primo-Millo, and M. Agustí. 2012. Gibberellic acid reduces flowering intensity in sweet orange [Citrus sinensis (L.) Osbeck] by repressing CiFT gene expression. J. Plant Growth Regul. 31:529-536, https://doi.org/10.1007/s00344-012-9263-y.

Nishikawa, F., T. Endo, T. Shimada, H. Fujii, T. Shimizu, and M. Omura. 2009. Differences in seasonal expression of flowering genes between deciduous trifoliate orange and evergreen Satsuma mandarin. Tree Physiol. 29:921-926, https://doi.org/10.1093/treephys/tpp021.

Peres, N.R., N.L. Souza, S.E. Zitko, and L.W. Timmer. 2002. Activity of benomyl for control of postbloom fruit drop of citrus caused by $\mathrm{Col}$ letotrichum acutatum. Plant Dis. 86:620-624, https://doi.org/10.1094/PDIS.2002.86.6.620.

Peres, N.A. and M.M. Dewdney. 2019. 2019-2020 Florida citrus production guide: Postbloom fruit drop. Univ. Florida, Inst. Food Agr. Sci. Ext. Gainesville, FL. 15 Mar. 2020. <https://edis. ifas.ufl.edu/cg007>.

Peres, N.A., L.W. Timmer, J.E. Adaskaveg, and J.C. Correll. 2005. Lifestyles of Colletotrichum acutatum. Plant Dis. 89:784-796, https:// doi.org/10.1094/PD-89-0784.

Perondi, D., C.W. Fraisse, M.M. Dewdney, V.A. Cerbaro, J.H. Debastiani Andreis, A.B. Gama, G.J. Silva, Junior, L. Amorim, W. Pavan, and N.A. Peres. 2020. Citrus advisory system: A web-based postbloom fruit drop disease alert system. Comput. Electron. Agr. 178:105781, https://doi.org/10.1016/j.compag.2020.105781.

Pfaffl, M.W. 2001. A new mathematical model for relative quantification in real-time RT-PCR. Nucleic Acids Res. 29:e45, https://doi.org/ 10.1093/nar/29.9.e45.

Pillitteri, L.J., C.J. Lovatt, and L.L. Walling. 2004. Isolation and characterization of a TERMINAL FLOWER homolog and its correlation with juvenility in citrus. Plant Physiol. 135:1540-1551, https://doi.org/10.1104/pp.103.036178.

Plummer, J.A., M.G. Mullins, J.H. Vine, and R.P. Pharis. 1989. The role of endogenous hormones in shoot emergence and abscission in alternate bearing Valencia orange trees. Acta Hort. (239):341-344, https://doi.org/10.17660/ ActaHortic.1989.239.53.

R Core Team. 2020. R: A language and environment for statistical computing. 10 Jan. 2020. $<$ http://www.R-project.org/>.
Rieu, I. and S.J. Powers. 2009. Real-time quantitative RT-PCR design, calculations, and statistics. Plant Cell 21:1031-1033, https://doi.org/ 10.1105/tpc.109.066001

Rio, D.C., 2015. Denaturation and electrophoresis of RNA with formaldehyde Cold Spring Harb. Protoc. 2015:219-222, https:// doi:10.1101/pdb.prot080994.

Shalom, L., S. Samuels, N. Zur, L. Shlizerman, A. Doron-Faigenboim, E. Blumwald, and A. Sadka. 2014. Fruit load induces changes in global gene expression and in abscisic acid (ABA) and indole acetic acid (IAA) homeostasis in citrus buds. J. Expt. Bot. 65:3029-3044, https://doi.org/10.1093/jxb/eru148.

Shalom, L., S. Samuels, N. Zur, L. Shlizerman, H. Zemach, M. Weissberg, R. Ophir, E. Blumwald, and A. Sadka. 2012. Alternate bearing in citrus: Changes in the expression of flowering control genes and in global gene expression in ON- versus OFF-Crop Trees. PLoS One 7:e46930, https://doi.org/10.1371/journal.pone.0046930.

Sousa, E.M.R., C. Suzart, S.N. Costa, M.G.C. Costa, A.-A.F. de Almeida, M.A. Coelho Filho, F.R. da Silva, W. dos Santos Soares Filho, F. Micheli, and A. da Silva Gesteira. 2019. Transcriptomic analysis related to the flowering of the citrus hybrid Microcitrangemonia. Curr. Plant Biol. 18:100097, https://doi.org/10.1016/ j.cpb.2018.12.003.

Southwick, S.M. and T.L. Davenport. 1986. Characterization of water stress and low temperature effects on flower induction in citrus. Plant Physiol. 81:26-29, https://doi.org/10.1104/pp.81.1.26.

Stansly, P.A., J.A. Qureshi, L.L. Stelinski, and M.E. Rogers. 2019. 2018-2019 Florida citrus production guide: Asian citrus psyllid and citrus leafminer. Univ. Florida, Inst. Food Agr. Sci. Ext. Gainesville, FL. 15 Mar. 2020. $<$ https://edis.ifas.ufl.edu/in686>.

Stover, E., Y. Lin, X. Yang, and T. Vashisth. 2016. Hydrogen cyanamide on citrus: Preliminary data on phytotoxicity and influence on flush in potted and field trees. HortTechnology 26:839-845, https://doi.org/10.21273/HORTTECH03542-16.

Sun, T. 2008. Gibberellin metabolism, perception and signaling pathways in Arabidopsis. Arabidopsis Book 6:e0103, https://doi.org/10.1199/ tab.0103.

Talón, M., P. Hedden, and E. Primo-Millo. 1990. Gibberellins in Citrus sinensis: A comparison between seeded and seedless varieties. J. Plant Growth Regul. 9:201-206, https://doi.org/ 10.1007/BF02041963.

Tang, L. and C.J. Lovatt. 2019. Effects of low temperature and gibberellic acid on floral gene expression and floral determinacy in 'Washington' navel orange (Citrus sinensis L. Osbeck). Scientia Hort. 243:92-100, https:// doi.org/10.1016/j.scienta.2018.08.008.

Tang, L. S. Singh, and T. Vashisth. 2020. Association between fruit development and mature fruit drop in Huanglongbing-affected sweet orange. HortScience 55:851-857, https://doi.org/10.21273/HORTSCI149 31-20

Tang, L. and T. Vashisth. 2020. New insight in Huanglongbing-associated mature fruit drop in citrus and its link to oxidative stress Scientia Hort. 265:109246, https://doi.org/ 10.1016/j.scienta.2020.109246.

Timmer, L.W., J.P. Agostini, S.E. Zitko, and M Zulfiqar. 1994. Postbloom fruit drop of citrus, an increasingly prevalent disease of citrus in the Americas. Plant Dis. 78:329-334, https:// doi.org/10.1094/PD-78-0329. 
Timmer, L.W. and N.A. Peres. 2015. Where have all the flowers gone? Postbloom fruit drop of citrus in the Americas. Citrus Pathol. 2:1-6, https://doi.org/10.5070/ C421028302.
Valiente, J.I. and L.G. Albrigo. 2002. Modeling flowering date of sweet orange [Citrus sinensis (L.) Osbeck] trees in Central Florida based on historical weather records. Proc. Intl. Soc. Citrucult. IX Congr. 186-190.
Weigel, D., J. Alvarez, D.R. Smyth, M.F. Yanofsky, and E.M. Meyerowitz. 1992. LEAFY controls floral meristem identity in Arabidopsis. Cell 69:843-859, https://doi.org/10.1016/00928674(92)90295-N. 
Supplemental Table 1. Gene-specific primer sequences for gene expression analysis in 'Valencia' sweet orange with quantitative real-time polymerase chain reaction.

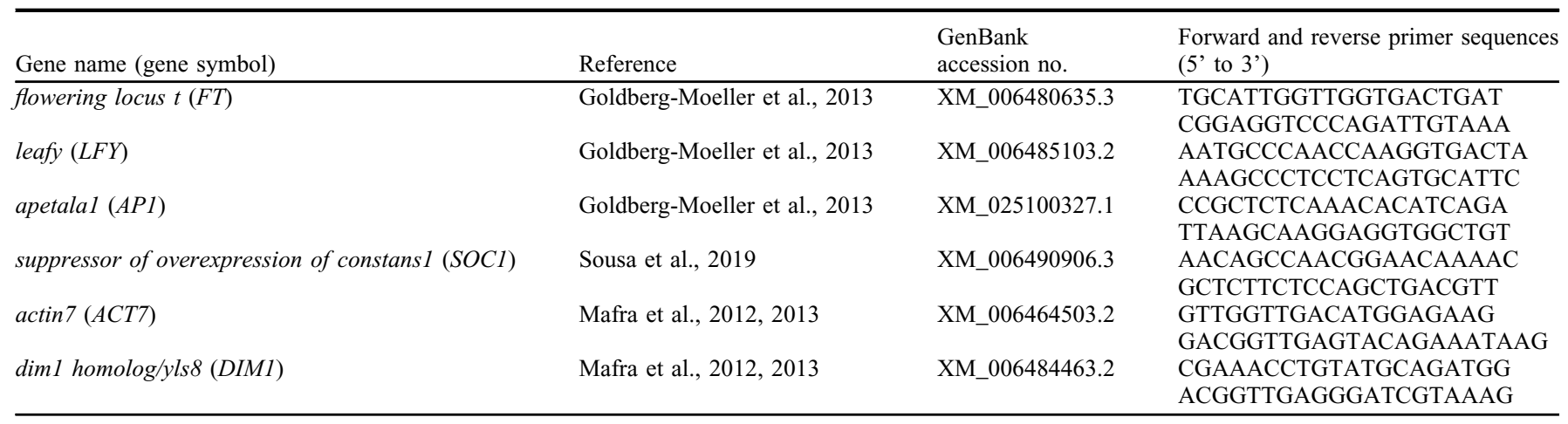
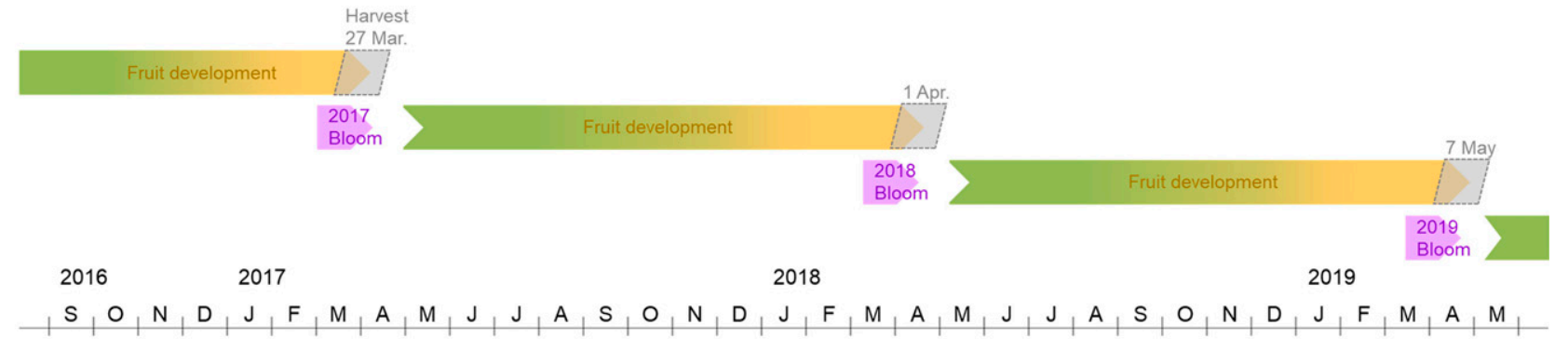

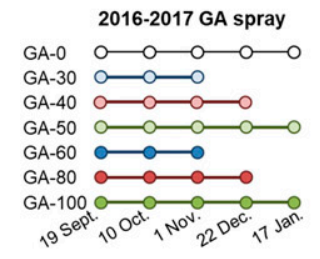

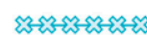
2017 flower count (incomplete)

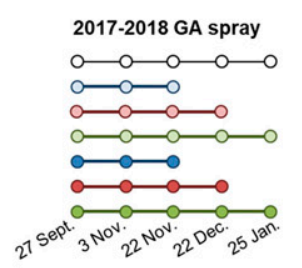

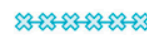

2018 flower coun

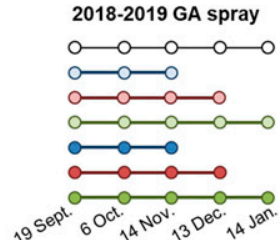

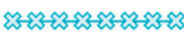
2019 flower count

Supplemental Fig. 1. Phenology of 'Valencia' sweet orange trees used in the current research based on field observations and the experimental design illustrating different gibberellic acid (GA) treatments over time in 3 years: untreated control (GA-0) and monthly GA applications from September to November, from September to December, and from September to January at the rate of $25 \mathrm{~g} \cdot \mathrm{ha}-1$ (GA-30, GA-40 and GA-50, respectively) and 49 g-ha-1 (GA60 , GA-80 and GA-100, respectively). 


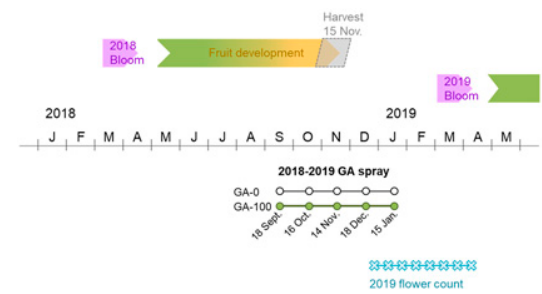

Supplemental Fig. 2. Phenology of 'Navel' sweet orange trees used in the current research based on field observations and the experimental design illustrating different gibberellic acid (GA) treatments over time: untreated control (GA-0) and monthly GA applications from September to January at the rate of $49 \mathrm{~g} \cdot \mathrm{ha}-1$ (GA-100)

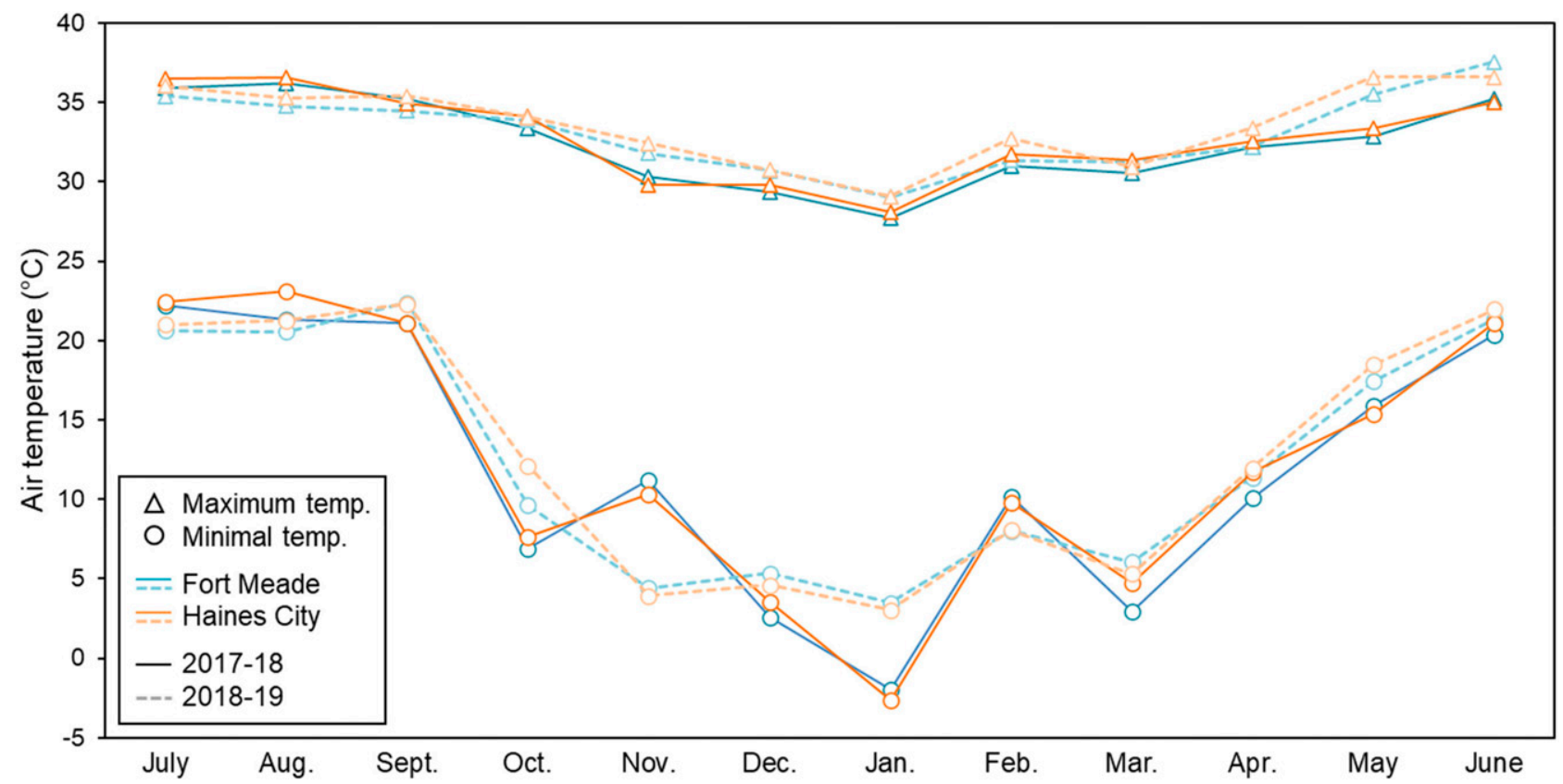

Supplemental Fig. 3. Monthly average maximum and minimum air temperatures in Fort Meade and Haines City in 2017-18 and 2018-19. 

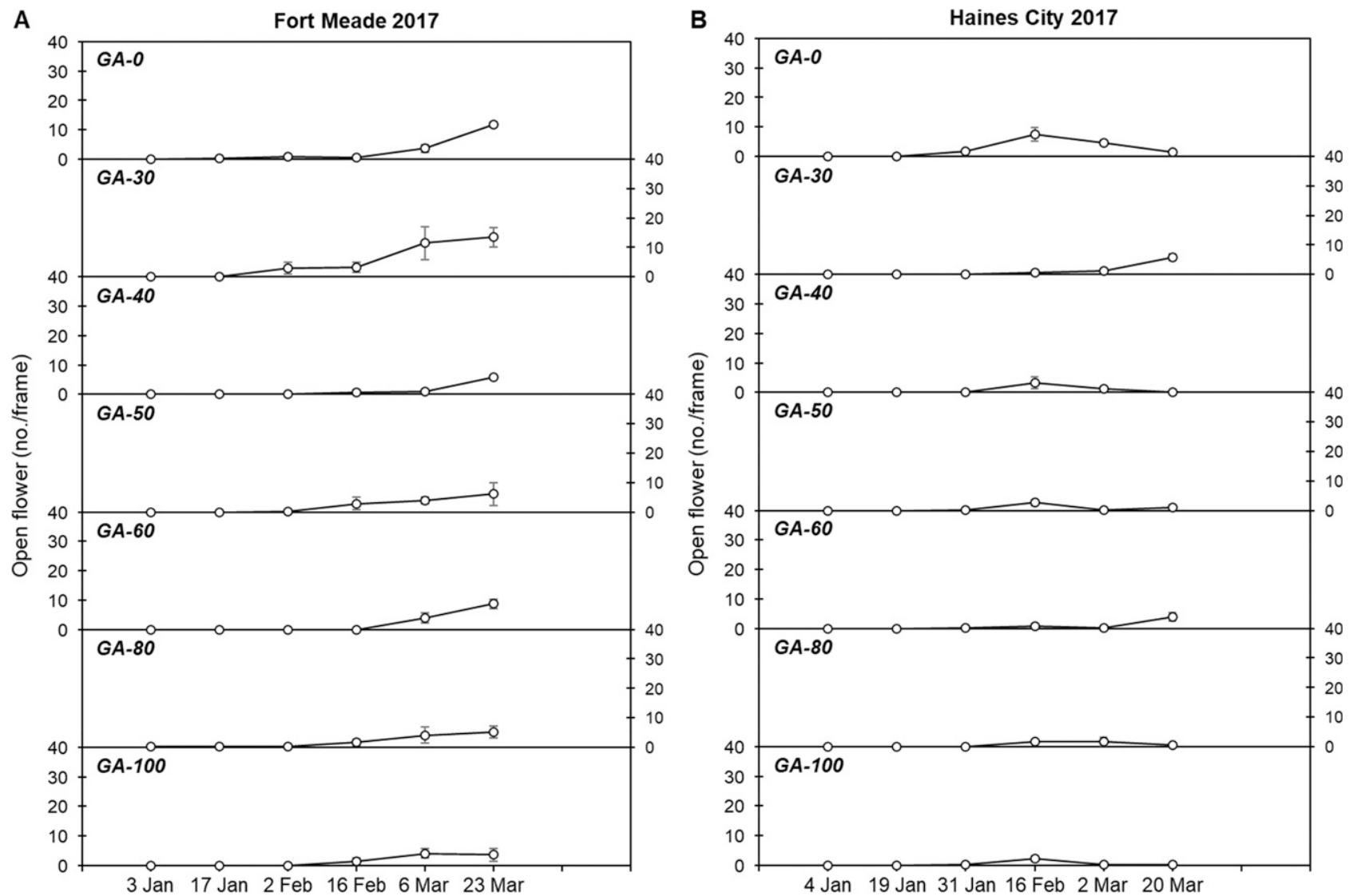

Supplemental Fig. 4. Number of open flowers in untreated control (GA-0) 'Valencia' sweet orange trees and trees applied with gibberellic acid monthly from September to November, from September to December, and from September to January at the rate of 25 (GA-30, GA-40 and GA-50, respectively) and 49 g.ha-1 (GA-60, GA-80 and GA-100, respectively) in Fort Meade (A) and Haines City (B) in 2017. Data are means \pm SD of four biological replicates. 
A

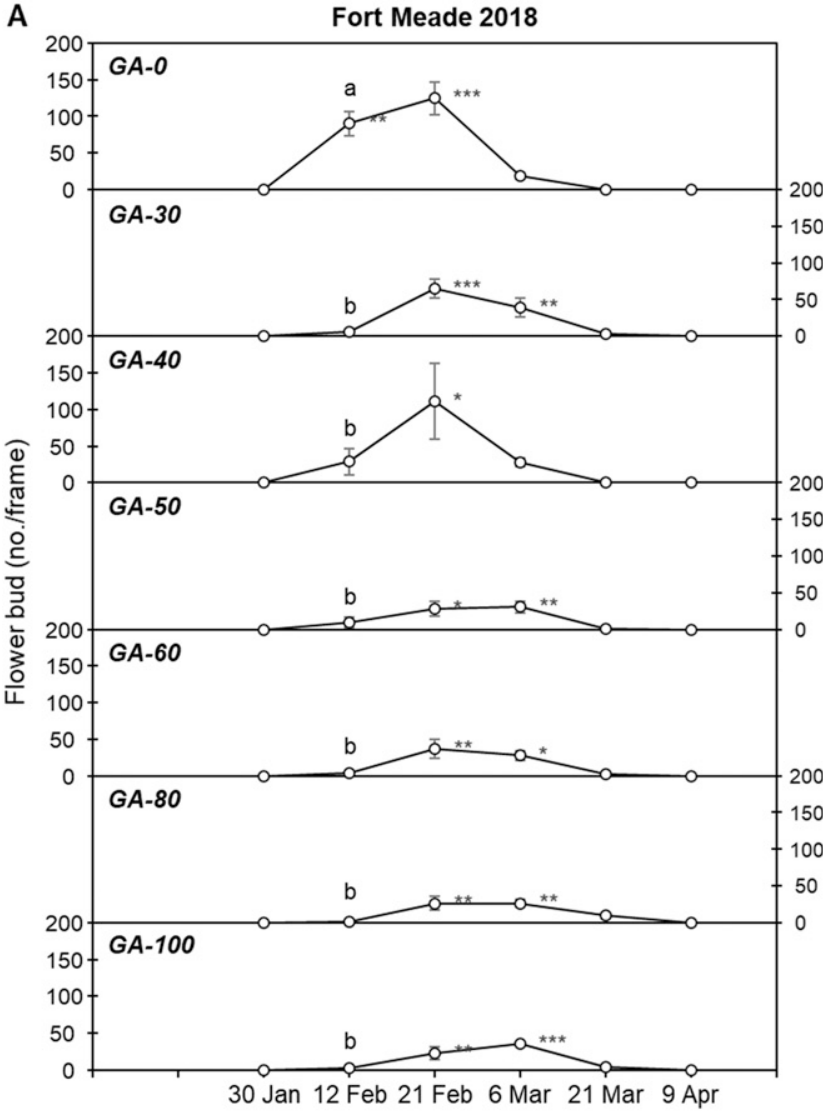

C

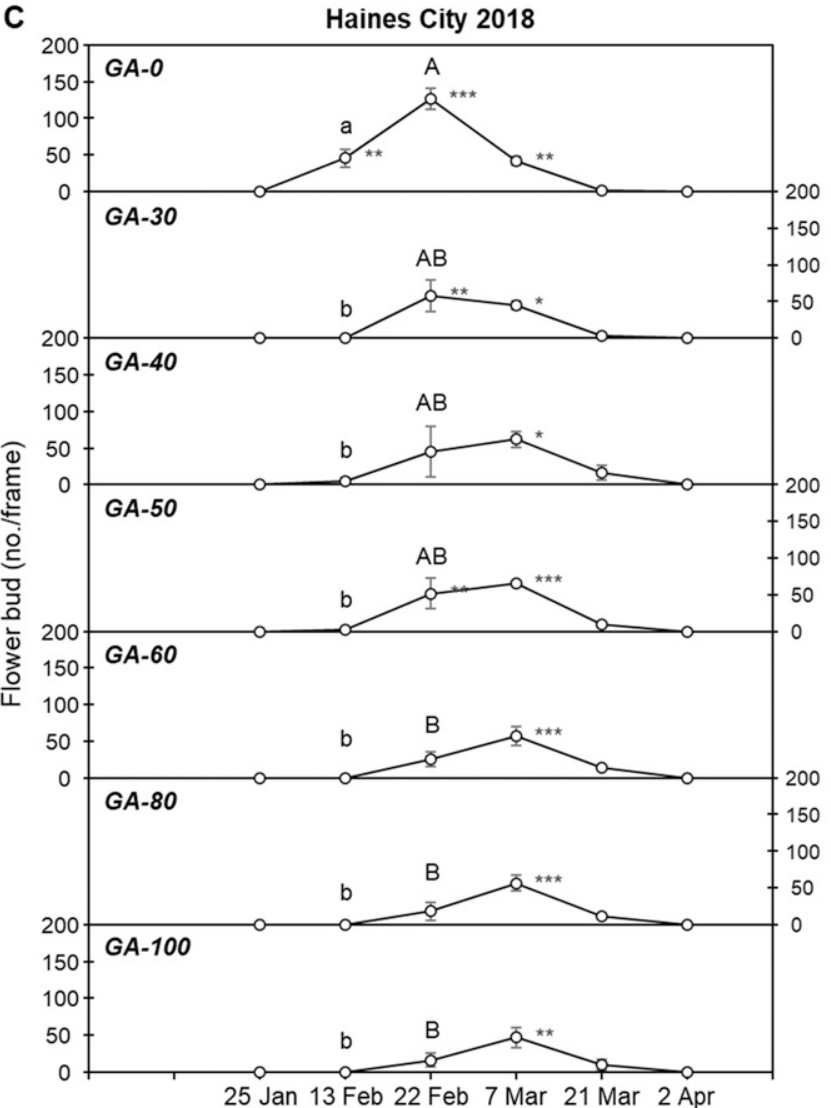

B

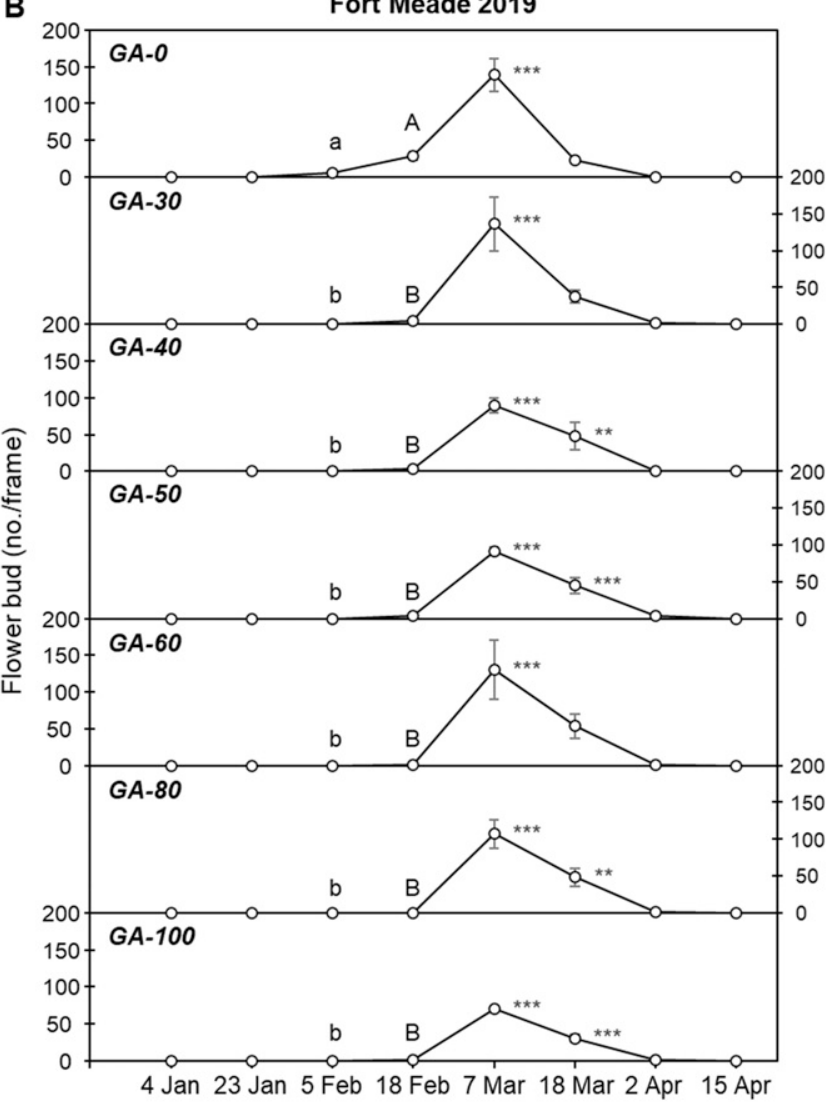

D

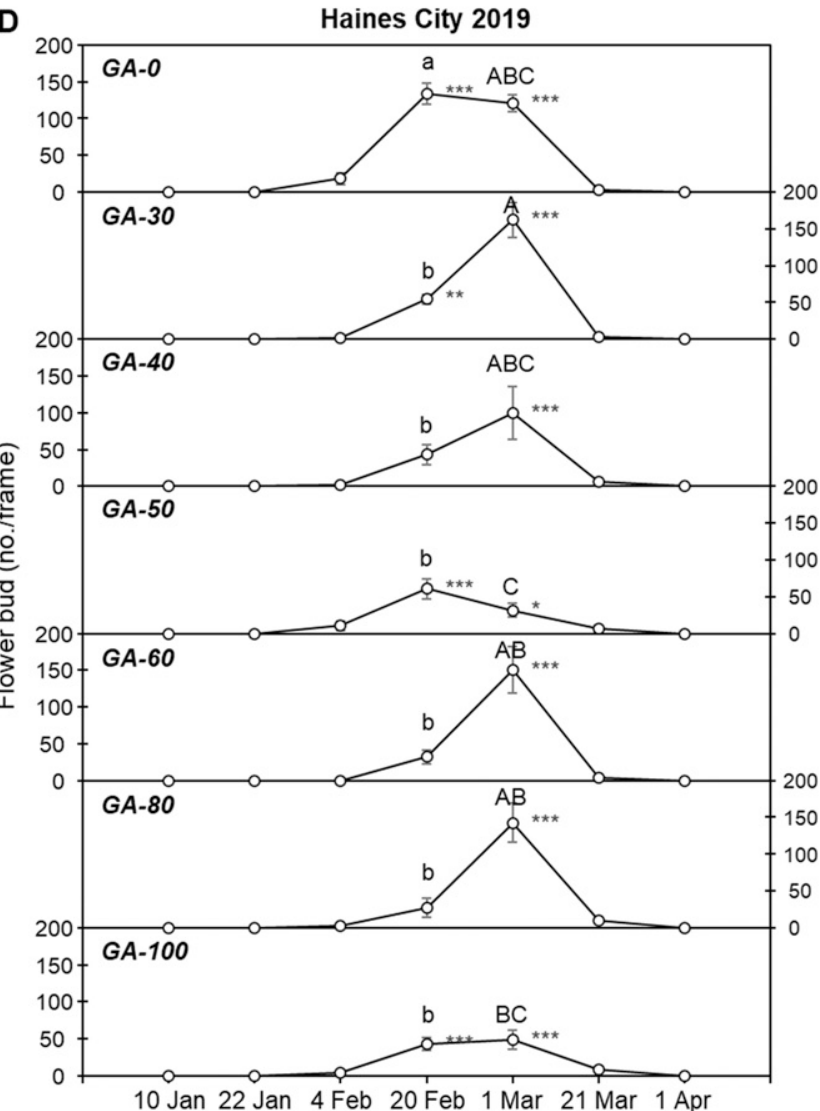

Supplemental Fig. 5. Number of elongated flower buds in untreated control (GA-0) 'Valencia' sweet orange trees and trees applied with gibberellic acid monthly from September to November, from September to December, and from September to January at the rate of 25 (GA-30, GA-40 and GA-50, respectively) and 49 g.ha-1 (GA-60, GA-80 and GA-100, respectively) in Fort Meade in 2018 (A) and 2019 (B) and Haines City in 2018 (C) and 2019 (D). Data are means \pm SD of four biological replicates. Within each treatment, asterisks indicate significant difference compared to the number on the first survey day based on Dunnett's test. Different lower and upper letters indicate significant differences $(\mathrm{P}<0.05)$ among treatments on the individual survey days. 